\title{
Uncertainties in break-up markers along the Iberia-Newfoundland margins illustrated by new seismic data
}

\author{
Annabel Causer ${ }^{1}$, Lucía Pérez-Díaz ${ }^{1,2}$, Jürgen Adam ${ }^{1}$, and Graeme Eagles ${ }^{3}$ \\ ${ }^{1}$ Earth Sciences Department, Royal Holloway University of London, Egham, TW20 0EX, UK \\ ${ }^{2}$ Department of Earth Sciences, Oxford University, Oxford, OX1 3AN, UK \\ ${ }^{3}$ Alfred Wegener Institut, Helmholtz Zentrum für Polar und Meeresforschung, Bremerhaven, Germany
}

Correspondence: Annabel Causer (annabel.causer.2017@live.rhul.ac.uk)

Received: 16 September 2019 - Discussion started: 30 September 2019

Revised: 4 February 2020 - Accepted: 17 February 2020 - Published: 30 March 2020

\begin{abstract}
Plate tectonic modellers often rely on the identification of "break-up" markers to reconstruct the early stages of continental separation. Along the Iberian-Newfoundland margin, so-called break-up markers include interpretations of old magnetic anomalies from the M series, as well as the "J anomaly". These have been used as the basis for plate tectonic reconstructions are based on the concept that these anomalies pinpoint the location of first oceanic lithosphere. However, uncertainties in the location and interpretation of break-up markers, as well as the difficulty in dating them precisely, has led to plate models that differ in both the timing and relative palaeo-positions of Iberia and Newfoundland during separation.

We use newly available seismic data from the Southern Newfoundland Basin (SNB) to assess the suitability of commonly used break-up markers along the Newfoundland margin for plate kinematic reconstructions. Our data show that basement associated with the younger M-series magnetic anomalies is comprised of exhumed mantle and magmatic additions and most likely represents transitional domains and not true oceanic lithosphere. Because rifting propagated northward, we argue that M-series anomaly identifications further north, although in a region not imaged by our seismic, are also unlikely to be diagnostic of true oceanic crust beneath the SNB. Similarly, our data also allow us to show that the high amplitude of the $\mathbf{J}$ Anomaly is associated with a zone of exhumed mantle punctuated by significant volcanic additions and at times characterized by interbedded volcanics and sediments. Magmatic activity in the SNB at a time coinciding with M4 (128 Ma) and the presence of SDR packages onlapping onto a basement fault suggest that, at this time,
\end{abstract}

plate divergence was still being accommodated by tectonic faulting.

We illustrate the differences in the relative positions of Iberia and Newfoundland across published plate reconstructions and discuss how these are a direct consequence of the uncertainties introduced into the modelling procedure by the use of extended continental margin data (dubious magnetic anomaly identifications, break-up unconformity interpretations). We conclude that a different approach is needed for constraining plate kinematics of the Iberian plate pre-M0 times.

\section{Introduction}

Over the past decade, plate tectonic modellers working on divergent settings have focused their efforts on betterconstraining the early stages of continental separation, partly driven by the oil and gas industry's move to more distal and deeper exploration targets (Péron-Pinvidic and Manatschal, 2009; Skogseid, 2010; Nirrengarten et al., 2017; Sandoval et al., 2019). As of today, bridging the gap between the onshore and offshore geological evolution of rifted continental margins still presents a challenge, due to the difficulty in unequivocally interpreting the complex geology of extended continental margins (Alves and Cunha, 2018; Keen et al., 2018).

When studying divergent settings, the onset of seafloor spreading is often based on so-called "break-up markers" that originate in tectonic interpretations made along the extended continental margins. Identified and mapped from geophysi- 
cal data, these features include depositional unconformities (e.g. Pereira and Alves, 2011; Soares et al., 2012; Decarlis et al., 2015), packages of landward-dipping reflectors (e.g. Keen and de Voogd, 1988), and seismic amplitude changes in the top-of-basement surface (e.g. Tucholke et al., 2007), interpreted as marking the change from continental to oceanic crust. These interpretations are utilized as the basis for many computer-generated plate reconstructions, which are in turn highly susceptible to uncertainties associated with the interpretation and mapping of said break-up markers. A recent global census and detailed analysis of these markers highlighted the very large average locational $(167 \mathrm{~km})$ and temporal ( $>5 \mathrm{Myr}$ ) uncertainties associated with defining them (Eagles et al., 2015).

Uncertainties of this kind, and their impact on tectonic reconstructions, have been illustrated by, for example, the alternative scenarios proposed in the literature for the movements of the Iberian plate between the Late Jurassic to Early Cretaceous (Srivastava et al., 1990, 2000; Sibuet and Collette, 1991; Sibuet et al., 2007; Greiner and Neugebauer, 2013; Barnett-Moore et al., 2016). Rotational poles derived from interpretations of the location of the continent-ocean boundary (COB), for example, have often resulted in overlaps of known continental crust along the Iberia-Africa plate boundary (e.g. Srivastava and Verhoef, 1992). Such overlaps are not present in kinematic models built on the basis of magnetic anomalies, which assume Iberia moves together with Africa for much of this time period (e.g. Sibuet et al., 2012). They are greatly reduced in so-called "deformable" plate models that account for continental margin deformation during continental break-up (Ady and Whittaker, 2018; Müller et al., 2019; Peace et al., 2019). Because these models undo stretching deformation, the large uncertainty in COB location estimates reduces to a much smaller uncertainty envelope of palinspastically restored equivalents (Eagles et al., 2015). This reduction is unlikely to be useful because, as those authors note, the restoration is achieved using rotations about a stage pole that is determined using an arbitrary choice of post-stretching $\mathrm{COB}$ estimate and whose formal statistical uncertainty is of a similar size to, or larger than, the restored envelope. Hence, the shape of the pre-stretching COB estimate is sensitive to post-stretching $\mathrm{COB}$ estimates to an extent that is likely to be larger than the uncertainty that the palinspastic reconstruction technique generates for it.

The West Iberia and Newfoundland margins are considered by many as the type example for magma-poor passive rifted margins (Boillot et al., 1995; Whitmarsh and Wallace, 2001; Reston, 2007; Tucholke and Sibuet, 2007; PéronPinvidic and Manatschal, 2009). The continental margins are the result of Late Triassic to Early Cretaceous rifting and separation of the North American and Eurasian plates. This pair of conjugate margins has been the focus of more than 40 years of intense research, including extensive geophysical surveying and drilling campaigns as part of the Ocean Drilling Programme (ODP) and Deep Sea Drilling Project
(DSDP) (e.g. Whitmarsh and Sawyer, 1996; Wilson et al., 1996). Research has revealed the margins' tectonic asymmetry and the gradual proximal-to-distal transition from regions of highly extended continental crust to zones of exhumed mantle locally intruded by pre- or post-break-up magmatic intrusions. Despite this, the detailed plate kinematics, the age of distinct rift episodes, the timing of the final break-up, and the significance of pre-existing structures and lithological heterogeneity are still heavily debated. The difficulty in identifying, mapping, and dating the COB along this pair of conjugate margins is evident in the wide range of candidate COBs suggested in the literature (Fig. 1) (i.e. Eagles et al., 2015 and refs. therein). The age of final breakup and formation of first oceanic crust is particularly uncertain. Drilling results and break-up unconformity identifications date the onset of seafloor spreading at the AptianAlbian transition (113 Ma) (Tucholke and Sibuet, 2007; Boillot et al., 1988). This is significantly younger than the age of the oldest isochrons interpreted from magnetic reversal anomalies (M20-145 Ma to M0-120 Ma) offshore of Iberia (Srivastava et al., 2000) (Fig. 1). The discrepancy means that the interpretation of these anomalies in terms of M-series isochrons is disputed. Although interpreted by some studies as markers of the first oceanic lithosphere (e.g. Vissers and Meijer, 2012; Sibuet et al., 2004), others have shown that they may instead be associated with igneous bodies located within zones of exhumed mantle (e.g. Sibuet et al., 2007, 2012).

Here we describe and interpret three previously unpublished 2D seismic profiles imaging the regional tectonic structure and crustal architecture of the southern Newfoundland margin from the shelf to the deepwater oceanic basin. The three profiles are chosen from among a large regional grid of data as the three most likely candidates for a conjugate to the IAM5 deep seismic profile on the Iberian margin and are thus suitable for a detailed assessment of the possible effects of across-axis asymmetry on uncertainties in break-up markers (see Pinheiro et al., 1992; Afilhado et al., 2008; Neves et al., 2009). Our interpretations underline and add to knowledge of the structural and kinematic complexity of the transitions between continental and oceanic crust at the Iberia-Newfoundland conjugate margins, specifically the Southern Newfoundland Basin (SNB), that contribute to the challenges faced by plate modellers when reconstructing this pair of conjugate margins. Our new seismic data show that, within the SNB, neither M-series magnetic anomalies nor the commonly used $\mathbf{J}$ anomaly are diagnostic of true oceanic crust. Extrapolating these regional observations beyond the extent of the SNB is challenging due to the high along-strike structural variability of the margin (e.g. Nirrengarten et al., 2018). As we will show, our extrapolations are consistent with the growing literature questioning the validity of these anomalies as kinematic markers for Iberia-Newfoundland kinematic modelling (e.g. Bronner et al., 2011; Stanton et al., 2016; Nirrengarten et al., 2017). 

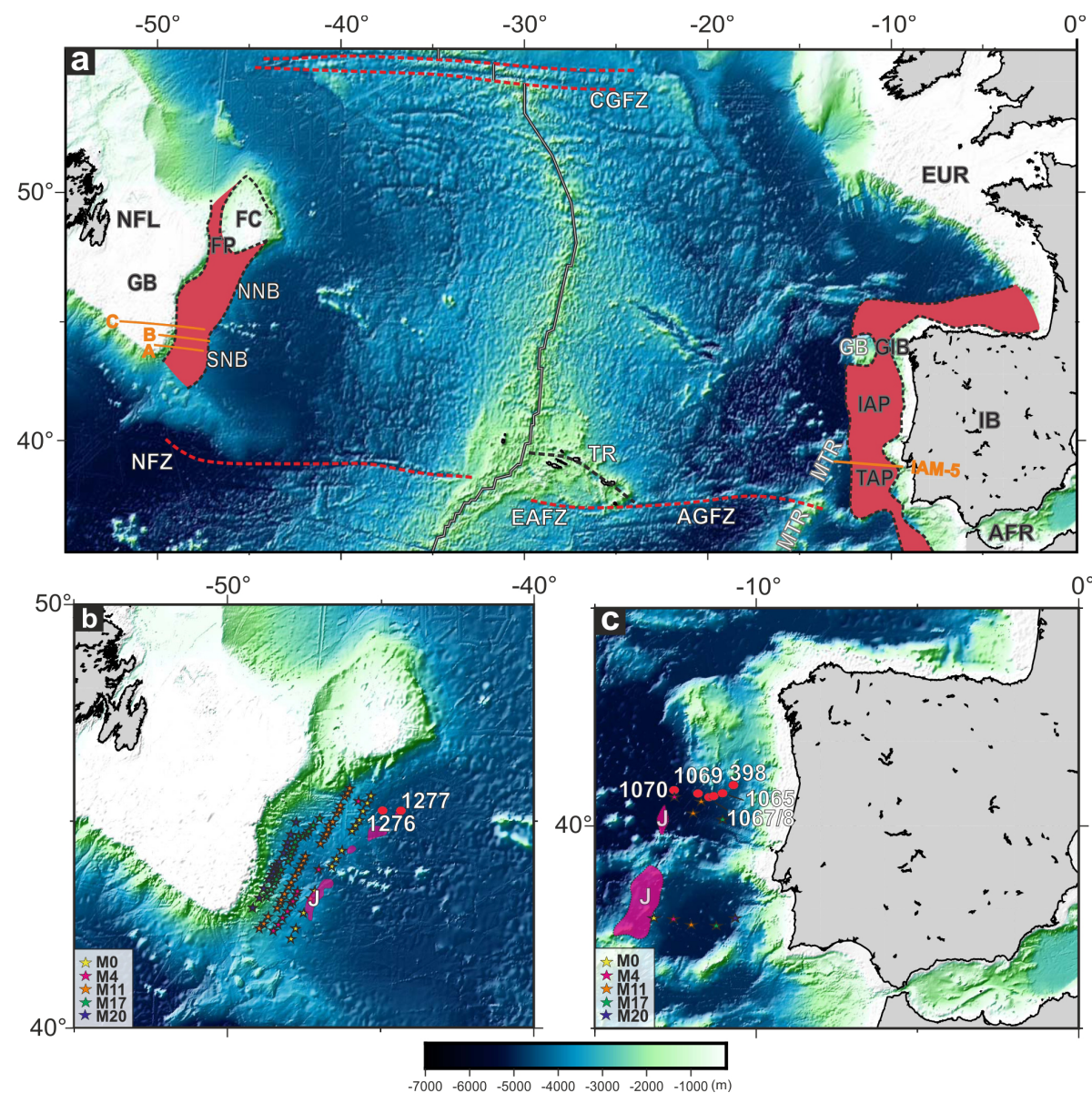

Figure 1. (a) Study area showing the location of structural and tectonic features significant to our study. Red envelopes mark the extent of the COTZ as compiled by Eagles et al. (2015). Double black line: mid-ocean ridge; red dashed lines: fracture zone traces. Orange lines: seismic profiles presented and discussed in this study. Background image is Smith and Sandwell (1997) gridded satellite altimetry. (b, c) Location of M-series magnetic isochron picks (Srivastava et al., 2000) and ODP legs 210 (Tucholke et al., 2007), 103 (Boillot et al., 1987), and 173 (Whitmarsh et al., 1988) drill sites. FC - Flemish Cap; FP - Flemish Pass; GB - Galicia Bank; GBA - Grand Banks; GIB - Galicia Interior Basin; IAP - Iberian Abyssal Plain; IB - Iberia; MTR - Madeira Tore Rise; NFL - Newfoundland; NNB - Northern Newfoundland Basin; SNB - Southern Newfoundland Basin; TAP - Tagus Abyssal Plain.

Furthermore, we review a number of published studies in order to examine the uncertainties of available plate kinematic reconstructions of the Iberia-Newfoundland conjugate margin (Srivastava et al., 1990; Seton et al., 2012; Greiner and Neugebauer, 2013). We do this by (a) examining the locations, within our new seismic data, of break-up markers commonly used by those studies and (b) utilizing these published rotation schemes to reconstruct conjugate margin transects into their pre-drift positions, examining the consequences of choosing alternative rotation parameters.

\section{Study area - tectonic evolution and controversies}

The formation of the Iberian-Newfoundland conjugate margins are primarily a result of a series of northward propagating Late Triassic to Early Cretaceous episodes of rift- ing (Manatschal and Bernoulli, 1999; Wilson et al., 2001; Alves et al., 2009). Progressive extension and final localization of the divergent plate boundary at a mid-ocean ridge led to the separation of the North American and the Iberian plates. Unlike the classic textbook examples of passive margin architecture, continental and oceanic crust are not juxtaposed along these margins but separated by a very wide continent-ocean transition zone $(150-180 \mathrm{~km}$; Eagles et al., 2015) (Fig. 1). Geophysical research into the IberianNewfoundland margins has, to an extent, illustrated the gradual change from continental crust through structurally complex regions of exhumed continental mantle and to purely oceanic crust (e.g. Dean et al., 2015). Although transition zones like this have been widely studied over the past decade (e.g. Whitmarsh and Wallace, 2001; Manatschal et al., 2001; Pérez-Gussinyé and Reston, 2001; Péron-Pinvidic and Manatschal, 2009; Mohn et al., 2012), the identification so-called 
break-up features, which cannot be confidently attributed to either crustal type, renders kinematic reconstructions based on them difficult and susceptible to large uncertainties. In the literature, this transition is often referred to as continentocean transition zone (COTZ) (Minshull et al., 1998; Dean et al., 2000; Davy et al., 2016).

The complex architecture of the Iberian-Newfoundland margins is the result of a sequence of extensional deformation episodes beginning with an initial "wide-rift" phase during Late Triassic to earliest Jurassic times (Manspeizer, 1988; Manatschal and Bernoulli, 1998; Tucholke et al., 2007; Péron-Pinvidic et al., 2007), followed by the localization of extension and related crustal thinning along the distal part of the future margins. This resulted in the exhumation of subcontinental mantle rocks within the transition zones, which formed prior to seafloor spreading sometime in the Early Cretaceous (Malod and Mauffret, 1990; Manatschal and Bernoulli, 1999; Dean et al., 2000; Péron-Pinvidic et al., 2007; Tucholke et al., 2007). The exact age of the onset of seafloor spreading is controversial and has, on the basis of regional correlations, magnetic anomaly interpretations, and drilling results, been inferred to date from as early as Valanginian (Wilson et al., 2001) or Barremian (Whitmarsh and Miles, 1995; Russell and Whitmarsh, 2003) to as late as around the Aptian-Albian boundary (Tucholke et al., 2007; Péron-Pinvidic et al., 2007; Mauffret and Montadert, 1987; Boillot et al., 1988; Eddy et al., 2017).

One of the difficulties in reconstructing the separation of the Iberian-Newfoundland margins is presented by the complex kinematic history of the Iberian plate (Barnett-Moore et al., 2016; Nirrengarten et al., 2017; Ady and Whittaker, 2018; Peace et al., 2019). Although currently part of the Eurasian plate, the Iberian plate moved independently between the Late Jurassic and sometime in the Paleogene (Fig. 2). During the Late Jurassic to Early Cretaceous, the Iberian plate was separated from the African, North American and European plates by divergent plate boundaries (Le Pichon and Sibuet, 1971) (Fig. 2a-c). During the Aptian time, relative motions between the African, Iberian, and Eurasian plates underwent a period of re-organization (Roest and Srivastava, 1991; Pinheiro et al., 1996; Rosenbaum et al., 2002; Seton et al., 2012; Tavani et al., 2018). It is broadly accepted that the Iberian plate undertook an anticlockwise rotation of around $35^{\circ}$ with respect to the Eurasian plate, resulting in the opening of the Bay of Biscay along its northern margin (Fig. 2b-c) (Van der Voo, 1969; Choukroune, 1992; Sibuet et al., 2004; Gong et al., 2008). Considerable controversy still exists as to the exact nature, timing, and consequences of this rotation, with conflicting scenarios having been proposed by authors based on interpretations of geological and geophysical observations (Olivet et al., 1984; Srivastava et al., 2000; Gong et al., 2008; Vissers and Meijer, 2011). Kinematic reconstructions can be split into two endmember groups. In one, the Bay of Biscay is depicted as having opened in a scissor-like fashion, with the hinge of the scissors located in the southeastern corner of the Bay of Biscay (Srivastava et al., 2000) (as shown in Fig. 2d). In the other, opening happens in a left lateral manner (Olivet, 1996). The anticlockwise rotation of Iberia as recorded in palaeomagnetic data (e.g. Gong et al., 2008) is most closely replicated by models depicting a scissor-type opening (Srivastava et al., 2000). However, models like these imply significant compression further east along the IberiaEurasia plate boundary (e.g. Schoeffler, 1965; Matthews and Williams, 1968; Masson and Miles, 1984; Roest and Srivastava, 1991; Sibuet and Collette, 1991; Sibuet and Srivastava, 1994; Srivastava et al., 1990, 2000; Cadenas et al., 2018; Peace et al., 2019), which is not supported by field geology (Lagabrielle et al., 2010; Tugend et al., 2014). In contrast to the modelled major crustal thickening, the presence of numerous bodies of subcontinental mantle rocks exposed along the North Pyrenean Zone suggests the formation of extensional basins during the Cretaceous (Bodinier et al., 1988; Lagabrielle et al., 2010; Vauchez et al., 2013; Tugend et al., 2014, 2015; Teixell et al., 2018). Although some authors have interpreted these basins as having formed in a back-arc setting resulting from the subduction of older oceanic lithosphere from north of Iberia beneath Europe (Sibuet et al., 2004; Vissers and Meijer, 2012), they can also be understood together with the opening of the Bay of Biscay as results of oblique-divergent motion between Iberia and Europe, along the North Pyrenean Fault (e.g. Olivet, 1996; Lagabrielle and Bodinier, 2008). Although in this model the fit of Iberia and Eurasia, derived by fitting the prominent regional magnetic $\mathbf{J}$ Anomaly, deteriorates to the north, it is favoured by many (Stampfli et al., 2002; Jammes et al., 2009; Handy et al., 2010).

Partial closure of the Bay of Biscay between Late Cretaceous and Oligocene times led to the formation of the Pyrenees (Bullard et al., 1965; Van der Voo, 1969; Muñoz, 2002; Sibuet et al., 2004; McClay et al., 2004; Gong et al., 2008) (Fig. 2e-f). In the early Miocene, the plate boundary between Iberia and Eurasia became inactive and the Iberian plate was incorporated into the Eurasian plate (Van der Voo and Boessenkool, 1973; Grimaud et al., 1982; Sibuet et al., 2004; Roest and Srivastava, 1991; Vissers and Meijer, 2012) so that the boundary between Eurasia and Africa ran south of Iberia and into the North Atlantic along the Azores-Gibraltar Fracture Zone (AGFZ) (Le Pichon and Sibuet, 1971; Sclater et al., 1977; Grimaud et al., 1982; Olivet et al., 1984; Roest and Srivastava, 1991; Zitellini et al., 2009). The present-day AGFZ (Fig. 1) is a complex plate boundary that accommodates relatively small differences between Eurasian-North American and African-North American seafloor spreading rates and directions along the Mid-Atlantic Ridge in the forms of minor extension at its western end (Searle, 1980), right-lateral strike-slip along its middle reach, and transpression in the east (e.g. Grimison and Chen, 1986; Srivastava et al., 1990; Jiménez-Munt and Negredo, 2003). 

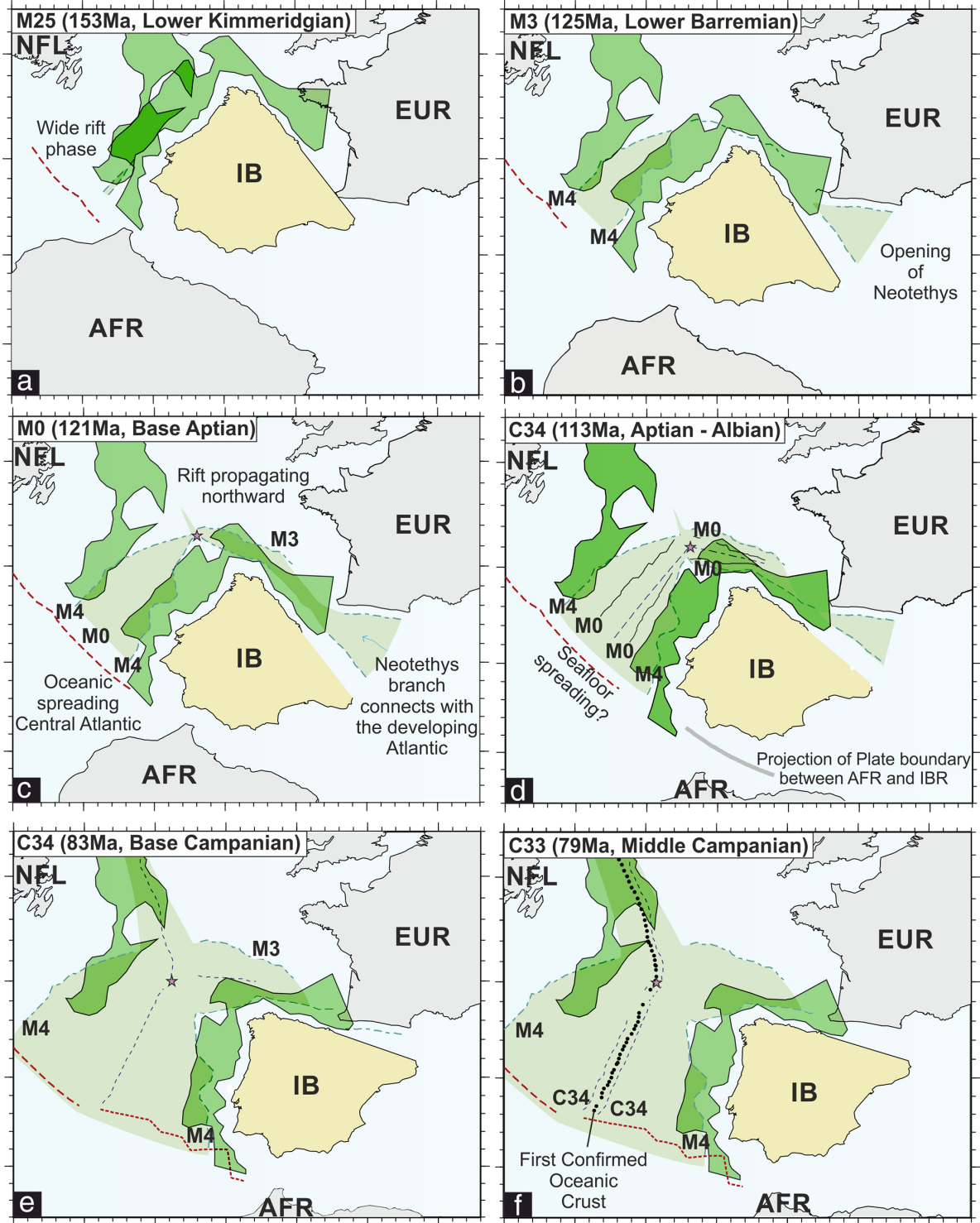

Figure 2. Six stages of development of the North Atlantic, from Late Jurassic to Late Cretaceous. Bright green envelopes show the maximum extent of the COTZ (Eagles et al., 2015). Light green shading shows oceanic lithosphere extent according to Sibuet et al. (2007) for the Atlantic and Sibuet et al. (2004) for the Bay of Biscay. Pink star: location of the triple junction between Eurasia-Iberia-North America. Adapted from Vissers and Meijer (2012).

\subsection{Break-up markers along the Iberian-Newfoundland margins}

It is generally agreed that statistical fitting of fracture zone trends and oceanic isochrons determined from magnetic anomalies is the most accurate method of modelling the relative motions of plates for the last $200 \mathrm{Myr}$ (Müller et al., 1997; Seton et al., 2012). This is a consequence of the relatively small locational error and relatively high interpretational confidence compared to other geological and geophysical markers (Müller et al., 2008; Seton et al., 2012; Eagles et al., 2015). However, the presence of magnetic reversal anomalies is not of itself diagnostic of crustal type, particularly along passive margins with wide transitional zones, such as the Iberian-Newfoundland margins. Within COTZs, it is possible that magnetic anomalies resulting from the presence of intrusive igneous bodies within the upper crust or exhumed subcontinental mantle can be erroneously attributed to basaltic oceanic crust (e.g. Cannat et al., 2008). Similarly, oceanic crust formed at mid-ocean ridges that are overlain by a significant thickness of sediment (Levi and Riddihough, 1986) or formed at ultra slow spreading centres may not give rise to strong magnetic signatures (Roest and Srivastava, 1991; Jokat and Schmidt-Aursch, 2007). 
Accordingly, whilst some researchers have interpreted magnetic anomalies as isochrons dating back to the Late Jurassic (chron M20, 146 Ma) to model relative motions of the Iberian and North American plates (Srivastava et al., 2000), their utility can be disputed by contradictory geological evidence from drill core data. At Site 1070 on the Iberian margin (Fig. 1), for instance, serpentinized peridotite was drilled from the location of a magnetic anomaly that had been previously defined in terms of seafloor spreading at the time of chron M1 ( 125 Ma; Whitmarsh et al., 1996; Tucholke and Sibuet, 2007). Similarly, at ODP Site 1277 basement associated with M1 has recently be interpreted as asthenospheric melts emplaced prior or coeval to mantle exhumation at $115 \mathrm{Ma}$ (Eddy et al., 2017). Numerous seismic surveys off both the Iberian and Newfoundland margins interpret the presence of transitional crust oceanwards of M0 (120 Ma), the youngest of the M-series isochrons (Shillington et al., 2006; Dean et al., 2015; Davy et al., 2016).

Several other M-series isochrons have been interpreted along the North Atlantic margins from magnetic anomalies that are often characterized by a somewhat subdued ( $<100 \mathrm{nT}$ amplitude; Fig. 3b) magnetic signature. Although their sources too are debated and sometimes suggested to lie within domains of exhumed mantle and thinned continental crust (Russell and Whitmarsh, 2003; Sibuet et al., 2004), their apparent symmetry across the rift and parallel trend with respect to the continental margins has led many researchers to interpret them as indicators of the presence of old oceanic lithosphere, pre-Albian in age. The uncertainties in the origin and interpretation of these anomalies also contribute to the generally large set of discrepancies between plate kinematic reconstructions of Iberia and to understanding the development of the Bay of Biscay in Late Jurassic to Early Cretaceous times (e.g. Srivastava et al., 1990, 2000; Whitmarsh and Miles, 1995; Barnett-Moore et al., 2016). For example, tectonic models using the M0 anomaly (125 Ma) result in a gap between eastern Iberia and Europe, the closure of which is difficult to reconcile with geological and geophysical data from the Pyrenees (Van der Voo, 1969; Gong et al., 2008; Lagabrielle et al., 2010; Tugend et al., 2014).

\subsubsection{The J anomaly}

In addition to the interpretations of M-series isochrons, a number of researchers have used a further regional magnetic lineation, known as the $\mathbf{J}$ anomaly, as a kinematic marker of the onset of seafloor spreading.

First acknowledged by Pitman and Talwani (1972), the J anomaly is a high-amplitude anomaly identifiable on each side of the southern North Atlantic Ocean south of the Galicia Bank and Flemish Cap regions (Fig. 3a). Based on its high amplitude and apparent symmetry across the rift, many have favoured the use of the $\mathrm{J}$ Anomaly over the $\mathrm{M}$ series as a kinematic marker. As a result, the $\mathrm{J}$ Anomaly has formed a basis for many plate kinematic reconstructions of the Iberia-
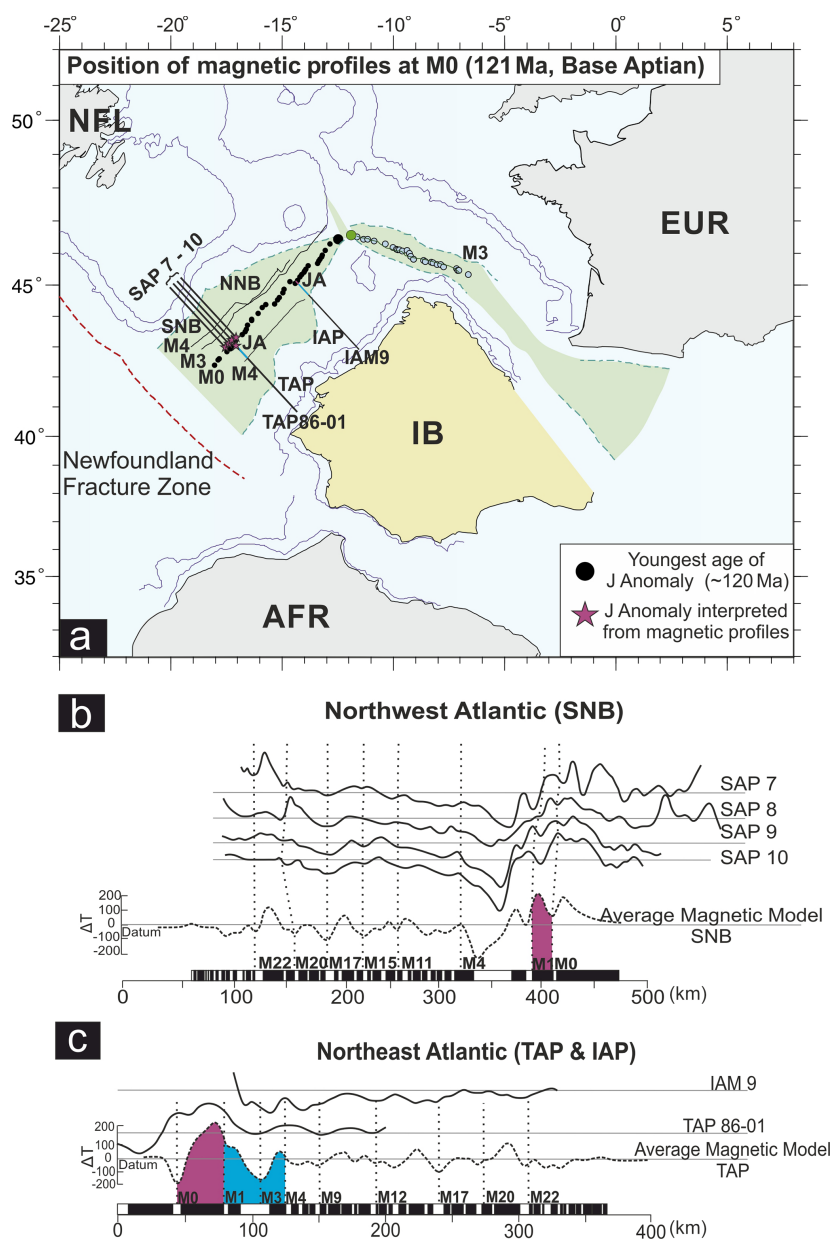

Figure 3. (a) Location of magnetic profiles across the Southern Newfoundland Basin and conjugate Tagus Abyssal Plain shown in (b) and (c) respectively. (b) Four along-track magnetic anomaly profiles (solid black lines) from the SNB, shown alongside a synthetic anomaly isochron model for comparison (dashed line). Pink shading marks the high-amplitude J Anomaly, identified as M0-M1 by Rabinowitz et al. (1978). (c) Two along-track magnetic anomaly profiles (solid black lines) from the TAP, shown alongside a synthetic anomaly isochron model for comparison (dashed line). Pink and blue shading indicate the high-amplitude $\mathbf{J}$ Anomaly, identified as M0-M4 by Whitmarsh and Miles (1995). Panels (b) and (c) adapted from Srivastava et al. (2000). IAP - Iberian Abyssal Plain; JA - J Anomaly; NNB - Northern Newfoundland Basin; SNB - Southern Newfoundland Basin; TAP - Tagus Abyssal Plain.

Newfoundland conjugates (e.g. Srivastava et al., 1990, 2000; Sibuet et al., 2004).

The amplitude, from trough to peak, of the J Anomaly is generally $500-600 \mathrm{nT}$ in the SNB and conjugate Tagus Abyssal Plain (TAP) (Tucholke et al., 1989), reaching maxima of around $1000 \mathrm{nT}$ over the southeast Newfoundland Ridge and conjugate Madeira Tore Rise (Fig. 3b-c). The J Anomaly coincides with a structural step in the basement in 
the TAP (Tucholke and Ludwig, 1982) and with discontinuous basement ridges in the SNB (Tucholke et al., 1989).

The origin and subsequent significance of the $\mathrm{J}$ anomaly have been interpreted in two ways in published literature. The first of these interpretations suggests that the $\mathrm{J}$ anomaly is the oldest magnetic isochron of true oceanic origin formed by seafloor spreading and representative of the beginning of the M-series magnetic anomalies (Keen et al., 1977; Sullivan, 1983; Klitgord and Schouten, 1986). It may be interpreted as a superposition anomaly formed by spreading during the periods of isochrons M0-M1 (Rabinowitz et al., 1978; Tucholke and Ludwig, 1982) or M0-M4 (Whitmarsh and Miles, 1995) (Fig. 3b-c). In both cases, the J anomaly is seen as the boundary between first formed oceanic crust and exhumed mantle (Reston and Morgan, 2004).

The alternative interpretation of the $\mathbf{J}$ anomaly (Bronner et al., 2011) suggests that it expresses magmatic basement ridges dating from the late Aptian (120-113 Ma) during the time immediately preceding steady-state seafloor spreading. Both the unusually high amplitude and variable width of the $\mathbf{J}$ anomaly are explained by Bronner et al. (2011) as being the result of the interplay between excess surface magmatism and the locations of underplated bodies at depth. The apparent northward decrease in J anomaly amplitude and distance to chron C34 are interpreted as evidence for a northward propagating break-up. Agreeing with this line of interpretation, Nirrengarten et al. (2017) go on to question its validity as an indicator of first seafloor spreading processes, suggesting the $\mathbf{J}$ Anomaly is a result of multiple magmatic events which occurred both during and after the formation of oceanic crust. Conversely, Gillard et al. (2016) interpret the high-amplitude $\mathbf{J}$ Anomaly as a relic of syn-rift magmatism which occurred during mantle exhumation pre-dating the onset of seafloor spreading.

\section{Dataset and methods}

A well-constrained plate rotation scheme for the separation of the Iberian and Newfoundland margins could be used to align regional seismic transects and generate a virtual rift-spanning seismic transect at the point of breakup (Fig. 4). Currently, the difficulties of interpreting preCampanian seafloor and break-up markers from the margins mean that no such rotation scheme exists entirely independently of existing interpretations of presumed-conjugate pairs of seismic profiles. Work is underway on producing an independent model by combining the less controversial histories of pre-Campanian seafloor spreading between neighbouring Africa, North America, and Eurasia in a quantitative regional plate circuit model (Causer et al., 2020).

To add to the range of candidate conjugate profile pairs, we describe and interpret here a number of previously unpublished regional 2D seismic profiles in the SNB. The discussed seismic data were obtained from TGS-NOPEC's
Southeast Grand Bank 2014 dataset, which comprises 34 2D seismic lines covering a combined area of $10678 \mathrm{~km}^{2}$. The lines discussed were acquired using a Geostreamer 24 bit (GAS) with $31.25 \mathrm{~m}$ shot point interval from a $4880 \mathrm{in}^{3}$ airgun and a streamer which was $10050 \mathrm{~m}$ in length. Data processing comprised Kirchhoff curved ray pre-stack time migration and post-migration conditioning: F-X deconvolution, band-pass filter, scaling, and stretching to depth, providing high-resolution images of the crustal structure offshore of Newfoundland. Within the entire dataset, the three lines shown here were chosen as they were previously unpublished and span the portion of the margin where J- and Mseries anomalies are found. They extend from the continental slope through highly extended continental crust and into exhumed mantle domains. None of these seismic lines extend far enough oceanward to image acoustic basement that can be confidently attributed to true oceanic crust. They do, however, image transitional crust previously associated with the J anomaly (M4-M1; Whitmarsh and Miles, 1995).

The stratigraphic framework of the SNB has not been investigated in detail as part of this study. Due to the lack of drilling data, sediments have been grouped into synrift 1 , syn-rift 2 , break-up sequence, and post-rift packages based on seismic-stratigraphic observations. Syn-rift 1 corresponds to a sedimentary sequence that formed during faultcontrolled extension and is characterized by reflectors which mimic changes in basement structure, often short in length and at times chaotic, and onlapping structural highs. Synrift 2 is instead characterized by more continuous reflections, arising from what we interpret as infill strata deposited between the end of fault-controlled rifting and the onset of seafloor spreading, also known as "sag sequence" (Masini et al., 2014). Based on its high amplitude and continuous nature, we consider our break-up sequence to mark the rupture of the lithosphere and onset of seafloor spreading, which we later tentatively date as taking place near the Aptian-Albian boundary (e.g. Mauffret and Montadert, 1987; Boillot et al., 1988; Pinheiro et al., 1992; Tucholke et al., 2007; PéronPinvidic et al., 2007). Although new research (Alves and Cunha, 2018) in the conjugate TAP proposes the presence of two break-up sequences, the first of which initiated in Berriasian times (145 Ma), our new seismic dataset does not allow us to repeat such an interpretation. Finally, post-rift strata are found overlying a prominent unconformity. They have been dated at DSDP Site 398, on the Iberian margin (Fig. 1), as Cenomanian in age (Wilson et al., 1989; Alves et al., 2003; Soares et al., 2012).

\section{Results}

\subsection{Line A - southern Southern Newfoundland Basin}

Line A, located in the southern South Newfoundland basin, is a $444 \mathrm{~km}$ long margin-scale $2 \mathrm{D}$ seismic section, which im- 
ages the entire crust beneath the Grand Banks area and offshore of Newfoundland. Part of this line is shown in Fig. 5a. This 2D seismic section extends from the continental slope through the COTZ into the distal domain.

The crust of the continental shelf beneath the Southern Grand Banks is tectonically thinned by a crustal-scale rift margin fault seen in the landward part of the profile between 2 and 6-7 s TWT (Fig. 5). Its hanging wall is deformed by numerous landward-dipping intra-rift faults with variable offsets. At depth this large fault is traceable to around $10 \mathrm{~s}$ TWT, coinciding with our interpretation of the seismic Moho (Fig. 5b).

More distally, the margin is characterized by a series of domino-style rotated fault blocks, bounded by landwarddipping faults of varying displacements (Fig. 5b). At depth, these faults seem to terminate against a high-amplitude reflector traceable to depth (Fig. 5c). This high-amplitude reflector can be traced to the top basement and interpreted as an exhumation fault marking the distal extent of thinned continental lithosphere. Oceanward of this point, the basement is deformed by a series of alternating landward- and oceanward-dipping normal faults (Fig. 5d). This change in seismic character of the basement and its coincidence with the high-amplitude reflector can be interpreted as the transition from highly extended continental crust to exhumed mantle. Landward of this location, the continental crust in the rift basin has been thinned progressively via landward-dipping intra-rift faults and larger oceanward-dipping faults, possibly detached at depth (Fig. 5a-b). However, eastward of the high-amplitude reflector the imaging of acoustic basement is poor due to the presence of high-impedance post-rift strata.

In the most seaward part of the profile, high-amplitude reflectors are traceable within what we interpret as a volcanic edifice (Fig. 5c). Within it, reflectors dip in opposing directions, which may be a result of velocity pull-up (e.g. Magee et al., 2013). Short discontinuous reflectors within the volcanic edifice are observed to onlap on to syn-rift 1 strata and the interpreted top of the exhumed mantle (Fig. 5e). Although sediments associated with break-up and post-rift sequences also onlap this syn-rift 1 or basement high, their seismic character is noticeably different. onlapping reflectors within the volcanic edifice are shorter and brighter than and not as planar as those observed in the break-up and postrift sequences (Fig. 5e). Beneath these brighter non-planar reflections the basement is poorly imaged, Accordingly, we interpret the internal high-amplitude reflectors as sills, as interpreted elsewhere in the basin (e.g. Hansen et al., 2004) as well as on lines B and C. We have also tentatively identified a potential hydrothermal vent dyke, marked by a vertical zone of chaotic and low-amplitude reflectivity topped by a conical body situated on the flank of a basement high (e.g. Planke et al., 2005). Imaging beneath the edifice is poor, rendering interpretations of the underlying basement difficult.

\subsection{Line B - central Southern Newfoundland Basin}

Line B, located in the central Southern Newfoundland Basin, images a $264 \mathrm{~km}$ long crustal transect from unequivocal continental crust beneath the landward continental shelf, through highly extended continental crust in the COTZ, and into a zone of exhumed mantle with magmatic additions (Fig. 6ab).

The proximal part of the margin is characterized by numerous parallel oceanward-dipping normal faults following a staircase-like pattern. Their vertical extents are difficult to map with certainty. Some of these faults are seen to terminate downwards against a high-amplitude reflector, which we interpret as a deep-seated landward-dipping detachment fault originating at the basinward limit of continental lithosphere (Fig. 6c). Oceanward of this high-amplitude reflector, the transition from highly extended continental crust to zones of exhumed mantle is marked by a smoother seismic characteristic of top basement.

In the exhumed mantle zone, a prominent basement high bisects the break-up sequence. The internal structure of the high is poorly imaged, making interpretations within it challenging (Fig. 6d). Landward of this high, a series of large basement faults bound a relatively symmetrical $80 \mathrm{~km}$ wide sub-basin infilled with a thick syn-rift sedimentary sequence. Towards the seaward part of the profile we interpret a package of seaward-dipping reflectors (Fig. 6e), the top of which is marked by a high-amplitude reflector. This package coincides with the interpreted location of the $\mathrm{J}$ Anomaly. Here, by analogy to drilled margins with similar characteristics (e.g. the south Australian margin; Ball et al., 2013), we suggest the acoustic basement to comprise a mixture of sediments and lava flows. Laterally, SDRs are seen to onlap onto a fault, perhaps indicating a degree of control by extension processes on magmatism (Fig. 6e).

\subsection{Line C - northern Southern Newfoundland Basin}

Line C, located in the northernmost part of the Southern Newfoundland Basin, is a $444 \mathrm{~km}$ long section which images the continental margin across the Grand Banks and offshore of Newfoundland. Figure 7a-b shows a $180 \mathrm{~km}$ long oceanward segment of this seismic line, focusing on the continental shelf, highly extended continental crust, and the COTZ.

At the base of the continental slope, which is characterized by a series of oceanward-dipping faults, a landward-dipping high-amplitude reflector can be traced to a depth equivalent of $10 \mathrm{~s}$ TWT. Oceanward, the basement is characterized by regularly spaced landward-dipping domino-style rotated fault blocks (Fig. 7c), above which we identify the presence of sedimentary packages corresponding to syn-rift 1 , synrift 2 , and the break-up sequence.

As before, we tentatively interpret the transition between extended continental crust and transitional crust from the smoothing of top basement. The COTZ is presumed to be 


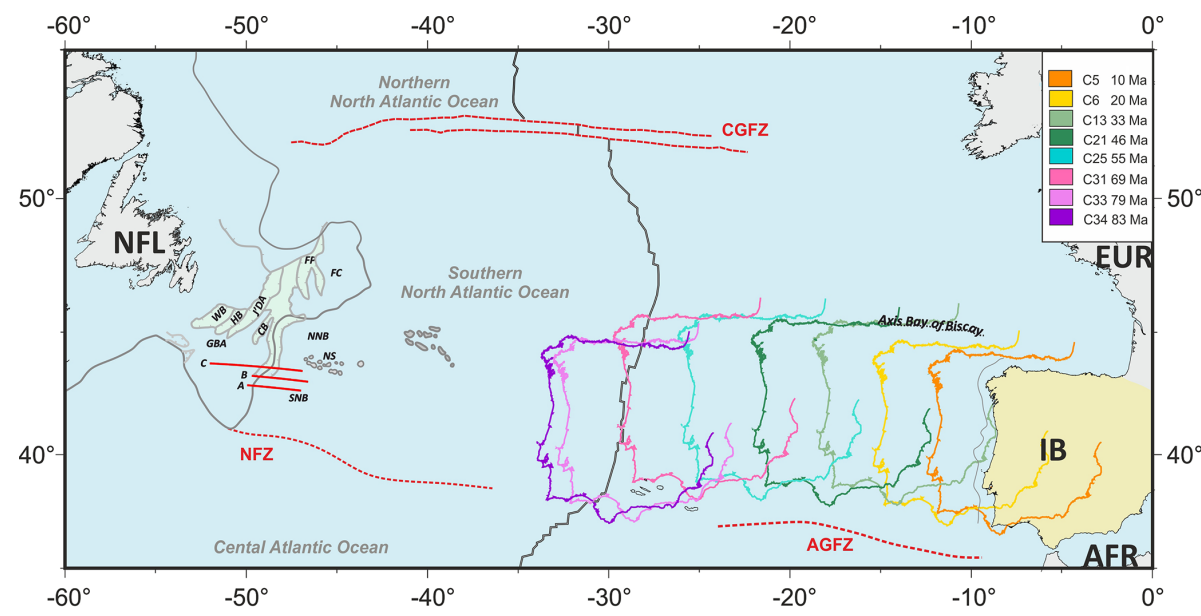

Figure 4. Map showing the positions of Iberia relative to North America from first unequivocal oceanic crust (83 Ma), as modelled by Seton et al. (2012) for C3-C6, Srivastava et al. (1990) for C13-C31 and C34, and Macchiavelli et al. (2017) for C33. Numerical chron ages are Gradstein et al. (2012). Red lines show the position of seismic sections A-C, provided by TGS. CB - Carson Basin; FC - Flemish Cap; FP Flemish Pass; GBA - Grand Banks; HB - Horseshoe Basin; NS - Newfoundland Seamounts; NNB - Northern Newfoundland Basin; SNB - Southern Newfoundland Basin; WB - Whale Basin.

floored by exhumed mantle, as recovered at sites 1276-1277 (Tucholke and Sibuet, 2007) further north in the Northern Newfoundland Basin (NNB). Within our interpreted region of exhumed mantle, individual fault blocks are no longer interpretable. The prominent basement high shown in Fig. 7d may be interpreted as a serpentinite diapir, as seen elsewhere within the Iberian Abyssal Plain and offshore of the Galicia Bank region (e.g. Boillot et al., 1980, 1995).

\subsection{IAM5 - Tagus Abyssal Plain}

The wide-angle $350 \mathrm{~km}$ long seismic profile IAM5 images crust from the continental slope into the distal domain of the TAP (Fig. 9). Although previously described in detail in the literature (e.g. Pinheiro et al., 1992; Afilhado et al., 2008; Neves et al., 2009), we take this section into consideration in order to provide an Iberian conjugate to the new seismic profiles described previously.

IAM5 is characterized by large oceanward-dipping and smaller landward-dipping basement faults in the COTZ, some of which propagate upwards into "undifferentiated" syn and post-rift sequences. A rise in basement toward the ocean is observed some $160 \mathrm{~km}$ from the base of the continental slope. Here, fault blocks still consistently dip toward the continent. Additionally in this distal domain, a highamplitude reflector is traceable above top basement, to $6 \mathrm{~s}$ TWT. Although the syn and post-rift break-up sequences are undifferentiated, the presence of sediments older than base Cenozoic has not been interpreted within this high (see Neves et al., 2009).

\section{Discussion}

The Iberia-Newfoundland margins have been extensively surveyed and studied over the past decade. The three seismic lines presented here, across the previously poorly documented SNB, further illustrate the complexity of this conjugate margin and are interpretable within the context of the existing and growing literature on extended continental margin processes. We interpret these lines as extending from the continental shelf through highly extended continental crust and into distal deepwater basin characterized by the presence of exhumed mantle.

Our interpretations of the geological and structural history of the SNB also allow us to speculate about the origin of magnetic anomalies previously interpreted as diagnostic of oceanic lithosphere and extensively used as grounds upon which to base plate tectonic reconstructions of the North Atlantic.

\subsection{Magnetic isochron interpretation: $M$ series and $J$ anomaly}

Some authors (e.g. Srivastava and Tapscott, 1986; Srivastava et al., 1990, 2000) identify the presence of M-series magnetic reversal isochrons from magnetic anomalies recorded along the Newfoundland margin, attributing them to the presence of oceanic lithosphere. Our results do not support such an interpretation. Instead, along both lines A (Fig. 5) and B (Fig. 6) these anomalies (M1-M4) are sourced within zones of exhumed mantle which, in places, may be intruded by magmatic additions of uncertain age. In Line B (Fig. 6), the interpreted $\mathrm{M}$-series isochrons coincide with the highamplitude oceanward-dipping reflectors that we interpret as 

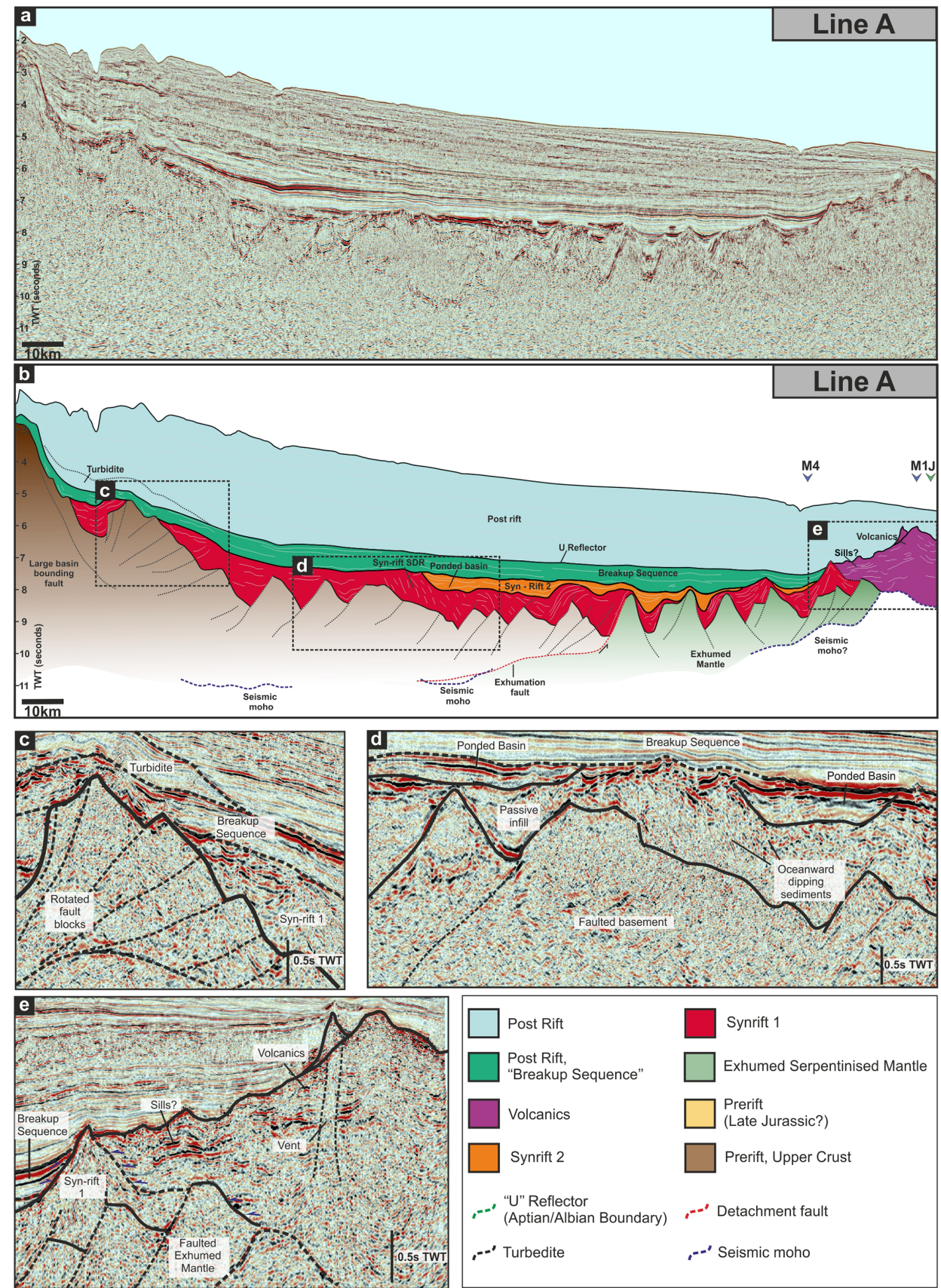

Figure 5. (a-b) Un-interpreted and interpreted seismic reflection profile ("Line A") from the southern Southern Newfoundland Basin. Interpretation shows the basement structure and sedimentary units. (c) Basement structure at the base of the continental slope. (d) Oceanwarddipping reflectors in syn-rift 1 sediments. (e) Volcanic edifice present in the proto-oceanic zone with associated sills and magmatic vents. All data courtesy of TGS.

SDR packages of interbedded volcanics and sediments. The formation of these features is usually associated with mantle dynamics during plate rupture rather than the formation of steady-state igneous crust (e.g. Keir et al., 2009). Here, they may indicate the "onset" of magmatic-driven extension (Tugend et al., 2018) preceding the establishment of seafloor spreading and production of true oceanic lithosphere. The volcanic edifice, sills, and feeder dykes in Line A (Fig. 5) may also be coeval with the final stages of plate rupture or a relic of post-rift magmatism (Stanton et al., 2016). Postrift volcanism associated with volcanism is generally associated with volcanic chains such as the Madeira Tore Rise or isolated seamounts identified in the Northern Newfoundland Basin (Nirrengarten et al., 2017). However, to date no 

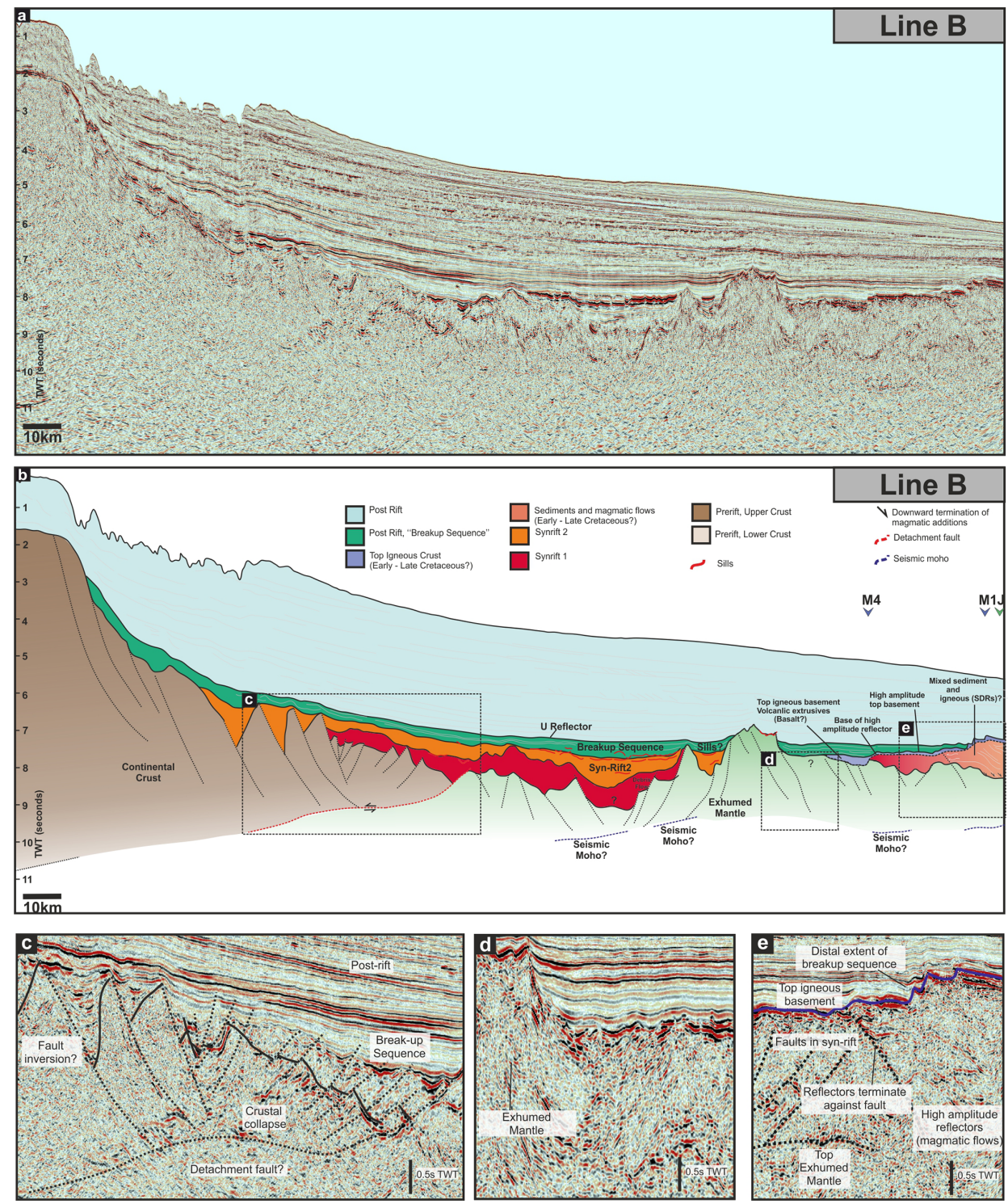

Figure 6. (a-b) Un-interpreted and interpreted seismic reflection profile ("Line B") from the central Southern Newfoundland Basin. Interpretation shows the basement structure and sedimentary units. (c) Crustal collapse of the hanging wall along a large-scale landward-dipping fault resulting in extremely thinned continental crust. (d) Section of syn-rift sediments within the exhumed mantle zone. (e) Bright-amplitude oceanward-dipping reflectors interpreted as a mixture of sediment and magmatic flows beneath an igneous top basement. All data courtesy of TGS.

seamounts as shown in Line A have been identified in the SNB.

Our interpretations align with those of Russell and Whitmarsh (2003) and Sibuet et al. (2004), who attribute the subdued amplitudes of the Newfoundland margins' magnetic anomalies to source bodies in highly extended continental crust and exhumed mantle rather than the upper layers of a "standard" $7 \mathrm{~km}$ thick oceanic crust.

Our seismic Line B (Fig. 6) images crust associated with the J Anomaly in the SNB. The anomaly coincides with an area of interpreted interbedded sedimentary and igneous packages, which are onlapping a basement fault. This might indicate that, at the time of magmatism, plate divergence was still controlled by tectonic faulting and the transition to seafloor spreading had not yet occurred. Although we acknowledge that the limited quantity of new data available to us is not, on its own, sufficient to draw a complete picture, it suggests that the $\mathrm{J}$ anomaly does not represent a boundary between purely oceanic lithosphere and exhumed mantle transitional domains (e.g. Reston and Morgan, 2004) but instead that its source lies within or on the latter.

Although our results suggest that M-series magnetic anomaly isochrons within the Newfoundland margin do not originate from purely oceanic lithosphere, they can be used 

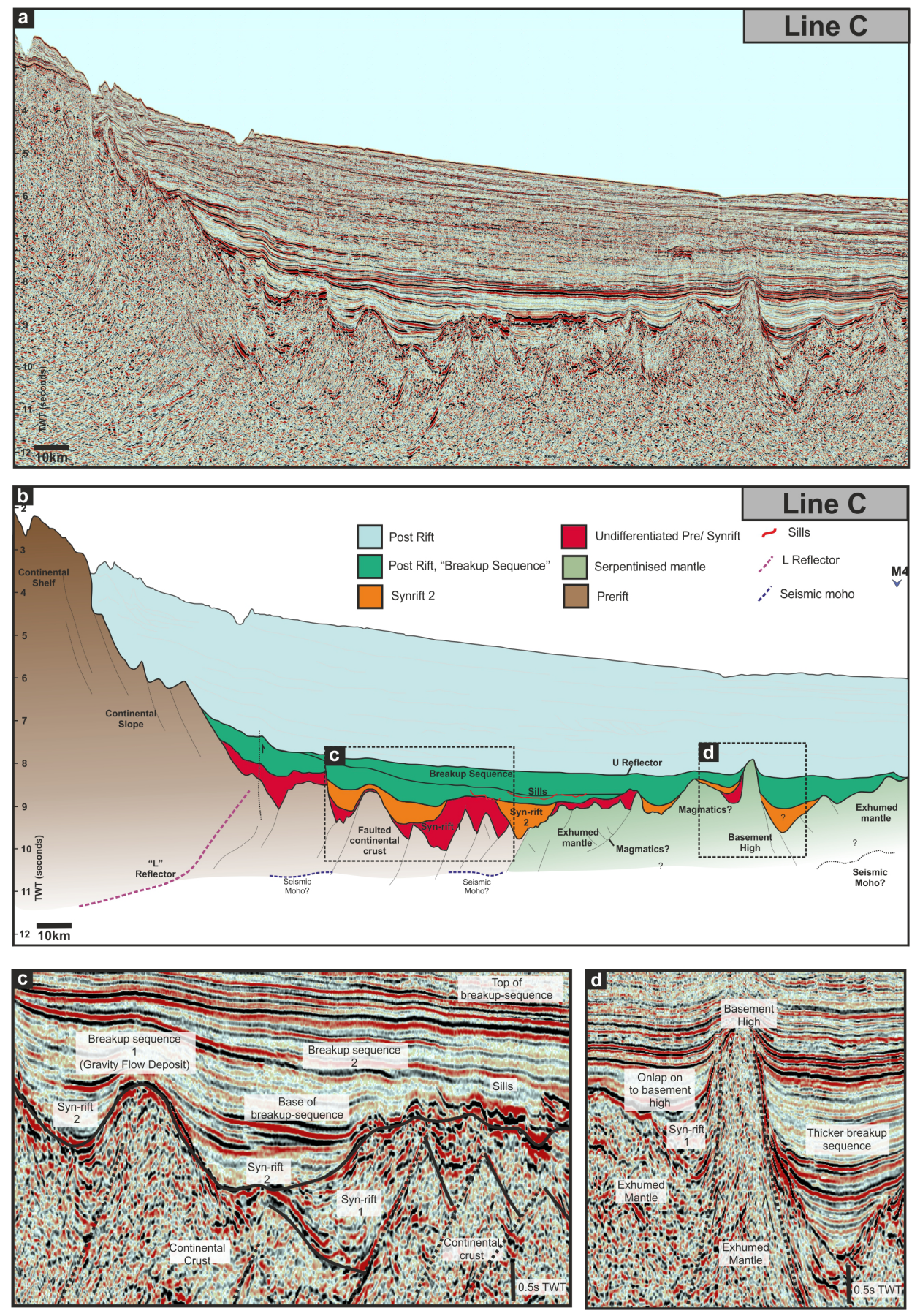

Figure 7. (a-b) Un-interpreted and interpreted seismic reflection profile ("Line C") from the northern Southern Newfoundland Basin. Interpretation shows the basement structure and sedimentary units. (c) Continental crust thinned by small normal faults. (d) Possible serpentinite diapir within the zone of exhumed mantle. All data courtesy of TGS.

to estimate the minimum possible age of the basement underlying them. Based on this, we suggest that the Newfoundland margin may have been magmatically influenced since the early Aptian (coinciding with M4, 128 Ma) (Fig. 5), earlier than previously thought (e.g. Tucholke and Ludwig, 1982; Tucholke et al., 2007; Stanton et al., 2016).
According to Bronner et al. (2011) the J Anomaly results from late Aptian (120-103 Ma) magmatism, preceding seafloor spreading. They suggested that northward propagating magmatism from which the $\mathrm{J}$ Anomaly originates began in the northern central Atlantic and was restrained at the Newfoundland Fracture Zone for $10 \mathrm{Myr}$ before reach- 

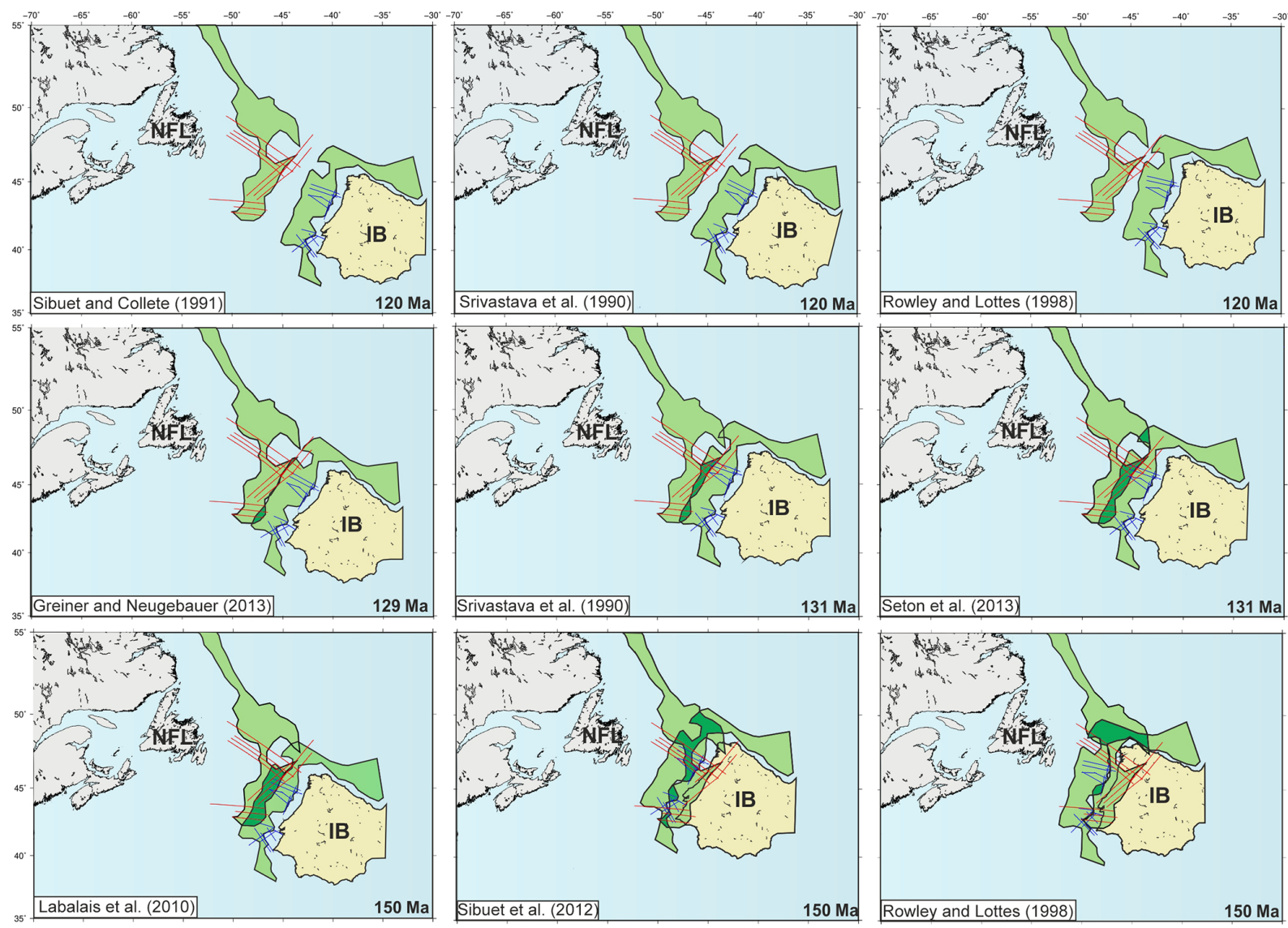

Figure 8. Reconstructions of the COTZ envelope from Eagles et al. (2015) at (a) Aptian, (b) Barremian, and (c) Tithonian ("full-fit") times, showing the range of virtual conjugates generated by alternative rotation schemes. Blue and red lines are the TGS Iberian and Newfoundland datasets, respectively. NFL: Newfoundland; IB: Iberia.

ing the NNB in the Iberian-Newfoundland rift at the AptianAlbian transition (112 Ma). Our results suggest a slightly different timing, with magmatic activity present in the SNB at a time coinciding with M4 (128 Ma), some 6-8 Myr younger than that proposed by Bronner et al. (2011). Although our data suggest an earlier age of magmatism than Bronner et al. (2011), we cannot comment on first ages of magmatism further north along margin.

Further north (e.g. Tucholke et al., 2007; Bronner et al., 2011; Nirrengarten et al., 2017), ODP drilling of rocks associated with the $J$ Anomaly in the NNB revealed a similar assemblage of exhumed mantle and intrusive and extrusive mafic rocks. The drilling results suggested that magmatic activity had been persistent from $\sim 128 \mathrm{Ma}(\mathrm{M} 4)$ to $\sim 70 \mathrm{Ma}$ (Jagoutz et al., 2007).

Although the J anomaly may be associated with events immediately preceding first seafloor spreading, these events are neither instantaneous in time nor isochronous along the margin, which renders the $\mathrm{J}$ Anomaly unsuitable as a kinematic marker.

\subsection{Conjugate pair matching}

The wide range of processes interpretable from our new data and previous studies of the Iberia-Newfoundland margins illustrates a degree of asymmetry that makes it impossible to unequivocally identify conjugate pairs of seismic transects from their geometric and stratigraphic characteristics alone. An alternative approach could be to select conjugates by rotating margin-wide seismic lines into coincidence at pre-drift times. However, the results of doing this are strongly dependent on the choice of rotation scheme and their inherent uncertainties. Figure 8 illustrates the wide range of pre-rift positions resulting from seven published plate kinematic models for Barremian times (Rowley and Lottes, 1988; Srivastava et al., 1990; Sibuet and Collette, 1991; Labails et al., 2010; Seton et al., 2012; Greiner and Neugebauer, 2013). Plate reconstructions to younger time slices are unsuitable for identifying conjugates; because of the significant underlap, they result in between the seismic surveys either side of the ocean. Similarly, full-fit reconstructions back to early Jurassic times result in large overlaps of the extended continental margins (Fig. 8). 


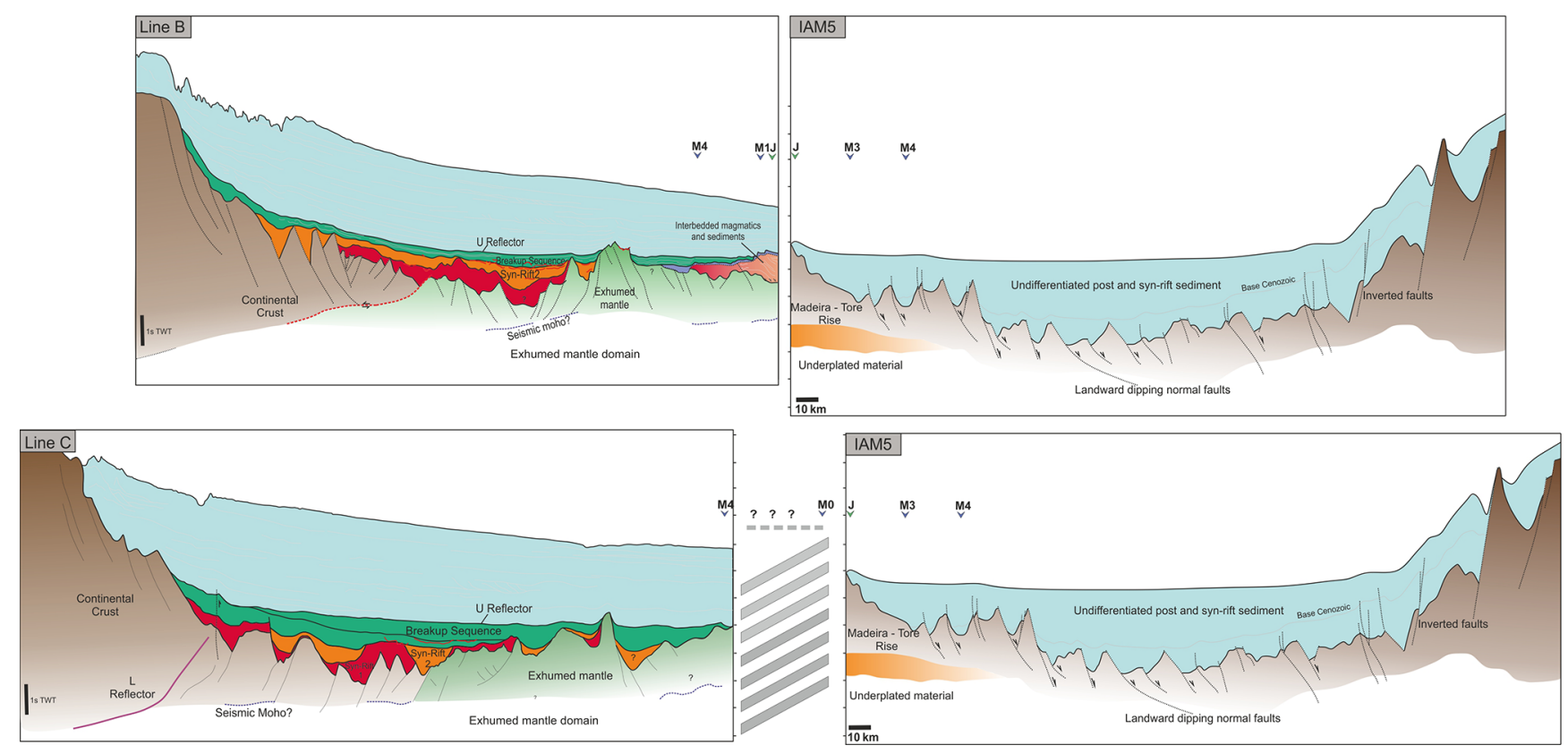

Figure 9. Comparison of "conjugate" seismic lines chosen on the basis of alternative rotation schemes for Barremian times. Conjugates according to (a) Greiner and Neugebauer (2013) and Seton et al. (2012) and (b) Srivastava et al. (1990). Conjugate comparisons are hung on $10 \mathrm{~s}$ TWT. Key as in Figs. 5-7.

Seton et al.'s (2012) reconstruction (Fig. 8b2) is based on an "extreme-oceanic" interpretation, with magnetic isochron picks in the sequence back to M20 (Srivastava and Tapscott, 1986; Srivastava et al., 2000). This model keeps Iberia fixed to Africa throughout Barremian times. Alternatively, the model of Greiner and Neugebauer (2013) (Fig. 8b1) relies on the magnetic dataset of Srivastava et al. (2000) alone to produce best-fitting reconstructions of $\mathrm{M}$-series isochrons interpreted from dense magnetic data off Newfoundland and sparser data off Iberia. In contrast, prior to chron M0, Srivastava et al.'s (1990) (Fig. 8b3) relies more strongly on seismic interpretations of conjugate changes in basement characteristics, conjugate fracture zones, and conjugate COB segments.

The reconstruction of Seton et al. (2012) results in significantly more overlap of the COTZ envelopes than that of Greiner and Neugebauer (2013). Overlaps in the COTZ suggest that the extended continental margins had not yet reached their present-day widths at this time. The early stages of continental separation, as described by these models, are subject to significant uncertainty, resulting from (a) the assumption that $\mathrm{M}$-series anomalies are of oceanic origin and (b) the difficulty in interpreting subdued magnetic signals. This is illustrated by the differences in the reconstructions produced by the models, shown in Fig. $8 \mathrm{~b} 1$ and b2. Despite the differences between the models of Greiner and Neugebauer (2013) and Seton et al. (2012), both suggest Line B as a conjugate to IAM5 prior to seafloor spreading (Fig. 9).

Alternatively, the model by Srivastava et al. (1990) suggests a conjugate pair consisting of Line $\mathrm{C}$ and IAM5
(Fig. 9). Their rotation scheme is derived from a model in which structural markers are used to constrain the position of Iberia during the Barremian, most notably Keen and de Voogd's (1988) COB, which they interpreted as coinciding with a prominent landward-dipping reflector (the L reflector, see Reid, 1994). The use of this feature shifts Iberia's palaeo-position $50-100 \mathrm{~km}$ further south than that modelled using identified magnetic isochrons alone.

The validity of the "L" reflector as a break-up marker can, however, be questioned on the basis of the huge variety of alternative COB interpretations published before and since Keen and de Voogd's (1988) study, which in this region differ by up to $200 \mathrm{~km}$ (Eagles et al., 2015). More specifically, Funck et al. (2003) identified the L Reflector offshore of Flemish Cap to lie well inboard of the COTZ within the continental slope. We tentatively interpret a high landwarddipping reflector traceable into the continental shelf in our Line C (Fig. 7), similar to the described L reflector thought to mark the COB.

Discriminating between "good" and "bad" reconstructions on the basis of the transects they reunite is clearly challenging. In the case discussed here, no strong arguments can be made regarding which of our new seismic lines (Line B or Line C) is the more likely conjugate to IAM5 based on their structural and stratigraphic characteristics. Neither line displays features which can be solely attributed to an upper or lower plate setting in asymmetric margins (e.g. Lister et al., 1986). The proximal domains of both Line B and C in the SNB are characterized by progressive continental lithosphere 
thinning by tectonic faulting, in places observed to terminate against large continent-dipping detachment faults. Faulting of continental lithosphere can also be observed on the Iberian side in line IAM5, although in this case detachment surfaces are not imaged. Across the interpreted transitional domains, exhumed mantle, diapirs, and extrusive flows are present in lines $\mathrm{B}$ and $\mathrm{C}$ but absent in line IAM5, where underplating has been suggested instead, although its age is uncertain (Mauffret et al., 1989; Peirce and Barton, 1991; Pinheiro et al., 1992; Bronner et al., 2011). The Madeira Tore Rise, located at the distal end of IAM5, results from alkaline magmatism post-dating break-up, which may also have resulted in the formation of volcanic edifices such as that seen in Line $\mathrm{A}$ in the SNB.

These observations illustrate the challenge of discriminating between good and bad rotation schemes on the basis of the conjugate transects they produce. This challenge could be greatly eased if informed by robust plate models built from high-confidence data with quantified uncertainties.

\section{Conclusions}

In this paper we have presented and described three new seismic transects from the Southern Newfoundland Basin and used them to discuss the validity of widely used so-called break-up markers along the Iberian-Newfoundland margins and the use of these features for plate kinematic modelling. In addition, we have illustrated the uncertainties in current plate models by restoring seismic transects to their pre-breakup locations utilizing existing rotation schemes of Barremian age. Interpretation of our new seismic dataset has revealed the following.

M-series magnetic anomalies are not diagnostic of true oceanic crust beneath the SNB. Instead they are attributed to susceptibility contrasts between zones of highly extended continental crust and exhumed mantle in the basin floor. Similarly, the high-amplitude $\mathrm{J}$ Anomaly coincides with a zone of exhumed mantle punctuated by significant volcanic additions and is at times characterized by interbedded volcanics and sediments.

In the southern part of the Newfoundland margin, we suggest J-anomaly source bodies to be the result of mantle dynamics preceding plate rupture. Previously published studies show that, further north, the $\mathrm{J}$ anomaly is either too weak to recognize or missing altogether. Although associated with events immediately preceding first seafloor spreading, these events are neither instantaneous in time nor isochronous along the margin, which renders the $\mathbf{J}$ Anomaly unsuitable as a kinematic marker.

Our results show that magmatic activity was underway in the SNB at a time coinciding with M4 (128 Ma), earlier than previously thought. SDR packages onlapping onto a basement fault suggest that, at this time, plate divergence was still being accommodated, at least partially, by tectonic faulting.
Differences in the relative positions of Iberia and Newfoundland according to published Barremian age plate reconstructions built on the basis of structural data vs. magnetic data illustrate the uncertainties introduced into the modelling procedure by the use of extended continental margin data (dubious magnetic anomaly identifications, break-up unconformity interpretations). In the SNB, we interpret the extent of the COTZ to reach oceanward to at least M0 (118 Ma). As a result, a complementary approach is needed for constraining plate kinematics of the Iberian plate pre-M0 times. In this respect we anticipate that the palaeo-position of Iberia could come to be more confidently reconstructed using a larger more comprehensive plate model that encompasses the central and southern North Atlantic Ocean.

Our new data and previous studies of the IberiaNewfoundland margins illustrate a diversity of features that define conjugate asymmetry and along-strike variability to the extent that it becomes impossible to unequivocally identify conjugate pairs of seismic transects from their geometric and stratigraphic characteristics alone. Although our new data do not provide sufficient clarity about conjugate pairs, they are helpful to clarify the temporal context for future plate kinematic reconstructions.

A robust plate kinematic model built from wellconstrained spreading data and involving a larger plate circuit would provide the basis to generate virtual rift-spanning seismic transects at the time of continental break-up. This, in turn, would make it possible to investigate further how the processes related to continental break-up are recorded in the sedimentary architecture of rifted margins. Such a plate model does not yet exist.

Data availability. Seismic data were supplied to us by TGS and are not publicly available. Other figures in this paper are created using data (e.g poles of rotation) which are already in circulation; reference to these data sources can be found in the figure caption.

Author contributions. AC drafted the original manuscript and figures, with contributions from all authors. LPD, GE, and JA further contributed to the refinement and improvement of the paper both before the original submission and through the review process.

Competing interests. The authors declare that they have no conflict of interest.

Special issue statement. This article is part of the special issue "Understanding the unknowns: the impact of uncertainty in the geosciences". It is not associated with a conference. 
Acknowledgements. We thank TGS NOPEC for the provision of the seismic data for this paper and the COMPASS Consortium, Royal Holloway University of London for funding support. We would also like to thank Alexander Peace for his fair and constructive review of our paper. Figures were produced using the Generic Mapping Tools (GMT; Wessel and Smith, 1991).

Financial support. This research has been supported COMPASS Consortium, Royal Holloway, University of London.

Review statement. This paper was edited by Juan Alcalde and reviewed by Alexander L. Peace, Frauke Klingelhoefer, and one anonymous referee.

\section{References}

Ady, B. E. and Whittaker, R. C.: Examining the influence of tectonic inheritance on the evolution of the North Atlantic using a palinspastic deformable plate reconstruction, Geol. Soc. Spec. Publ., 470, 245-263, https://doi.org/10.1144/sp470.9, 2018.

Afilhado, A., Matias, L., Shiobara, H., Hirn, A., MendesVictor, L., and Shimamura, H.: From unthinned continent to ocean: The deep structure of the West Iberia passive continental margin at $38^{\circ} \mathrm{N}$, Tectonophysics, 458, 9-50, https://doi.org/10.1016/j.tecto.2008.03.002, 2008.

Alves, T. M. and Cunha, T.: A phase of transient subsidence, sediment bypass and deposition of regressive-transgressive cycles during the breakup of Iberia and Newfoundland, Earth Planet. Sc. Lett., 484, 168-183, https://doi.org/10.1016/j.epsl.2017.11.054, 2018.

Alves, T. M., Manuppella, G., Gawthorpe, R. L., Hunt, D. W., and Monteiro, J. H.: The depositional evolution of diapirand fault-bounded rift basins: Examples from the Lusitanian Basin of West Iberia, Sediment. Geol., 162, 273-303, https://doi.org/10.1016/S0037-0738(03)00155-6, 2003.

Alves, T. M., Moita, C., Cunha, T., Ullnaess, M., Myklebust, R., Monteiro, J. H., and Manuppella, G.: Diachronous evolution of late jurassic-cretaceous continental rifting in the northeast atlantic (west iberian margin), Tectonics, 28, 1-32, https://doi.org/10.1029/2008TC002337, 2009.

Ball, P., Eagles, G., Ebinger, C., McClay, K., and Totterdell, J.: The spatial and temporal evolution of strain during the separation of Australia and Antarctica, Geochem. Geophy. Geosy., 14, 27712799, https://doi.org/10.1002/ggge.20160, 2013.

Barnett-Moore, N., Hosseinpour, M., and Maus, S.: Assessing discrepancies between previous plate kinematic models of Mesozoic Iberia and their constraints, Tectonics, 35, 1843-1862, https://doi.org/10.1002/2015TC004019, 2016.

Bodinier, J. L., Dupuy, D., and Dostal, J.: Geochemistry and petrogenesis of Eastern Pyrenean peridotites, Geochi. Cosmochim. Ac., 52, 2893-2907, https://doi.org/10.1016/00167037(88)90156-1, 1988.

Boillot, G., Grimaud, S., Mauffret, A., Mougenot, D., Kornprobst, J., Mergoil-Daniel, J., and Torrent, G.: Ocean-continent boundary off the Iberian margin: A serpentinite diapir west of the Galicia Bank, Earth Planet. Sc. Lett., 48, 23-34, https://doi.org/10.1016/0012-821X(80)90166-1, 1980.

Boillot, G., Winterer, E. L., and Meyer, A. W.: Introduction, Objectives, and Principal Results: Ocean Drilling Program Leg 103, West Galicia Margin, Proc. Ocean Drill. Program, 103, Initial Reports 3-17, College Station, TX, https://doi.org/10.2973/odp.proc.ir.103.101.1987, 1987.

Boillot, G., Girardeau, J., and Kornprobst, J.: The rifting of the Galicia margin: crustal thinning and emplacement of mantle rocks on the seafloor, Proc. Ocean Drill. Program, 103, 741-756, https://doi.org/10.2973/odp.proc.sr.103.179.1988, 1988.

Boillot, G., Beslier, M. O., Krawczyk, C. M., Rappin, D., and Reston, T. J.: The formation of passive margins: Constraints from the crustal structure and segmentation of the deep Galicia margin, Spain, Geol. Soc. Spec. Publ., 90, 71-91, https://doi.org/10.1144/GSL.SP.1995.090.01.04, 1995.

Bronner, A., Sauter, D., Manatschal, G., Péron-Pinvidic, G., and Munschy, M.: Magmatic beakup as an explanaion for magnetic anomalies at magma-poor rifed magins, Nat. Phys., 5, 85-85, https://doi.org/10.1038/nphys1201, 2011.

Bullard, E., Everett, J., and Smith, G. A.: The Fit of the Continents around the Atlantic, Philos. T. R. Soc. S.-A, 258, 41-51, https://doi.org/10.1098/rsta.1965.0020, 1965.

Cadenas, P., Fernández-Viejo, G., Pulgar, J. A., Tugend, J., Manatschal, G., and Minshull, T. A.: Constraints Imposed by Rift Inheritance on the Compressional Reactivation of a Hyperextended Margin: Mapping Rift Domains in the North Iberian Margin and in the Cantabrian Mountains, Tectonics, 37, 758-785, https://doi.org/10.1002/2016TC004454, 2018.

Cannat, M., Sauter, D., Bezos, A., Meyzen, C., Humler, E., and Le Rigoleur, M.: Spreading rate, spreading obliquity, and melt supply at the ultraslow spreading Southwest Indian Ridge, Geochem. Geophy. Geosy., 9, 1-26, https://doi.org/10.1029/2007GC001676, 2008.

Causer, A., Eagles, G., Pérez-Díaz, L., and Adam, J.: Plate kinematic modelling of the Central and North Atlantic Oceans, in preparation, 2020.

Choukroune, P.: Tectonic Evolution of the Pyrenees, Annu. Rev. Earth Pl. Sc., 20, 143-158, https://doi.org/10.1146/annurev.ea.20.050192.001043, 1992.

Davy, R. G., Minshull, T. A., Bayrakci, G., Bull, J. M., Klaeschen, D., Papenberg, C., Reston, T. J., Sawyer, D. S., and Zelt, C. A.: Continental hyperextension, mantle exhumation, and thin oceanic crust at the continent-ocean transition, West Iberia: New insights from wide-angle seismic, J. Geophys. Res.-Sol. Ea., 121, 767-787, https://doi.org/10.1002/2015JB012352, 2016.

Dean, S. L., Sawyer, D. S., and Morgan, J. K.: Galicia Bank ocean-continent transition zone: New seismic reflection constraints, Earth Planet. Sc. Lett., 413, 197-207, https://doi.org/10.1016/j.eps1.2014.12.045, 2015.

Dean, S. M., Minshull, T. A., Whitmarsh, R. B., and Louden, K. E.: Deep structure of the ocean-continent transition in the southern Iberia Abyssal Plain from seismic refraction profiles: the IAM-9 transect at $40^{\circ} 20 \mathrm{~N}$, J. Geophys. Res., 104, 7443-7462, https://doi.org/10.1029/1999JB900301, 2000.

Decarlis, A., Manatschal, G., Haupert, I., and Masini, E.: The tectono-stratigraphic evolution of distal, hyper-extended magmapoor conjugate rifted margins: Examples from the Alpine 
Tethys and Newfoundland-Iberia, Mar. Petrol. Geol., 68, 54-72, https://doi.org/10.1016/j.marpetgeo.2015.08.005, 2015.

Eagles, G., Pérez-Díaz, L., and Scarselli, N.: Getting over continent ocean boundaries, Earth-Sci. Rev., 151, 244-265, https://doi.org/10.1016/j.earscirev.2015.10.009, 2015.

Eddy, M. P., Jagoutz, O., and Ibañez-Mejia, M.: Timing of initial seafloor spreading in the Newfoundland-Iberia rift, Geology, 45, 527-530, https://doi.org/10.1130/G38766.1, 2017.

Funck, T., Hopper, J. R., Larsen, H. C., Louden, K. E., Tucholke, B. E., and Holbrook, W.: Crustal structure of the ocean-continent transition at Flemish Cap: Seismic refraction results, J. Geophys. Res., 108, 2531, https://doi.org/10.1029/2003JB002434, 2003.

Gillard, M., Manatschal, G., and Autin, J.: How can asymmetric detachment faults generate symmetric Ocean Continent Transitions?, Terra Nov., 28, 27-34, https://doi.org/10.1111/ter.12183, 2016.

Gong, Z., Langereis, C. G., and Mullender, T. A. T.: The rotation of Iberia during the Aptian and the opening of the Bay of Biscay, Earth Planet. Sc. Lett., 273, 80-93, https://doi.org/10.1016/j.epsl.2008.06.016, 2008.

Gradstein, F. M., Ogg, J. G., Schmitz, M., and Ogg, G. (Eds.): The Geological Time Scale 2012, Vol. 2, Elsevier, Amsterdam, https://doi.org/10.1016/C2011-1-08249-8, 2012.

Greiner, B. and Neugebauer, J.: The rotations opening the Central and Northern Atlantic Ocean: Compilation, drift lines, and flow lines, Int. J. Earth Sci., 102, 1357-1376, https://doi.org/10.1007/s00531-012-0860-6, 2013.

Grimaud, S., Boillot, G., Collette, B. J., Mauffret, A., Miles, P. R., and Roberts, D. B.: Western extension of the IberianEuropean plate boundary during the Early Cenozoic (Pyrenean) convergence: A new model, Mar. Geol., 45, 63-77, https://doi.org/10.1016/0025-3227(82)90180-3, 1982.

Grimison, N. L. and Chen, W.: The Azores-Gibraltar Plate Boundary: Focal mechanisms, depths of earthquakes, and their tectonic implications, J. Geophys. Res.-Sol. Ea., 91, 2029-2047, https://doi.org/10.1029/JB091iB02p02029, 1986.

Handy, M. R., Schmid, S., Bousquet, R., Kissling, E., and Bernoulli, D.: Reconciling plate-tectonic reconstructions of Alpine Tethys with the geological-geophysical record of spreading and subduction in the Alps, Earth-Sci. Rev., 102, 121-158, https://doi.org/10.1016/j.earscirev.2010.06.002, 2010.

Hansen, D. M., Cartwright, J. A., and Thomas, D.: 3D Seismic Analysis of the Geometry of Igneous Sills and Sill Junction Relationships, Geol. Soc. Mem., 29, 199-208, https://doi.org/10.1144/GSL.MEM.2004.029.01.19, 2004.

Jagoutz, O., Müntener, O., Manatschal, G., Rubatto, D., Péron-Pinvidic, G., Turrin, B. D., and Villa, I. M.: The rift-to-drift transition in the North Altantic: A stuttering start of the MORB machine?, Geology, 35, 1087-1090, https://doi.org/10.1130/G23613A.1, 2007.

Jammes, S., Manatschal, G., Lavier, L., and Masini, E.: Tectonosedimentary evolution related to extreme crustal thinning ahead of a propagating ocean: Example of the western Pyrenees, Tectonics, 28, 1-24, https://doi.org/10.1029/2008TC002406, 2009.

Jiménez-Munt, I. and Negredo, A. M.: Neotectonic modelling of the western part of the Africa-Eurasia plate boundary: From the Mid-Atlantic ridge to Algeria, Earth Planet. Sc. Lett., 205, 257271, https://doi.org/10.1016/S0012-821X(02)01045-2, 2003.
Jokat, W. and Schmidt-Aursch, M. C.: Geophysical characteristics of the ultraslow spreading Gakkel Ridge, Arctic Ocean, Geophys. J. Int., 168, 983-998, https://doi.org/10.1111/j.1365246X.2006.03278.x, 2007.

Keen, C., Hall, B., and Sullivan, K.: Mesozoic evolution of the Newfoundland Basin, Earth Planet. Sc. Lett., 37, 307-320, https://doi.org/10.1016/0012-821X(77)90176-5, 1977.

Keen, C. E. and de Voogd, B.: The Continent-Ocean Boundary at the rifted marin off Eastern Canada: New results from deep seismic reflection studies, Tectonics, 7, 107-124, https://doi.org/10.1029/TC007i001p00107, 1988.

Keen, C. E., Dickie, K., and Dafoe, L. T.: Structural Evolution of the Rifted Margin off Northern Labrador: The Role of Hyperextension and Magmatism, Tectonics, 37, 1955-1972, https://doi.org/10.1029/2017TC004924, 2018.

Keir, D., Bastow, I. D., Whaler, K. A., Daly, E., Cornwell, D. G., and Hautot, S.: Lower crustal earthquakes near the Ethiopian rift induced by magmatic processes, Geochem. Geophy. Geosy., 10, 1-10, https://doi.org/10.1029/2009GC002382, 2009.

Klitgord, K. D. and Schouten, H.: Plate kinematics of the central Atlantic, in: The Western North Atlantic Region, edited by: Vogt, P. R. and Tucholke, B. E., Geol. Soc. Am., https://doi.org/10.1130/DNAG-GNA-M.351, 1986.

Labails, C., Olivet, J.-L., Aslanian, D., and Roest, W. R.: An alternative early opening scenario for the Central Atlantic Ocean, Earth Planet. Sc. Lett., 297, 355-368, https://doi.org/10.1016/j.epsl.2010.06.024, 2010.

Lagabrielle, Y. and Bodinier, J. L.: Submarine reworking of exhumed subcontinental mantle rocks: Field evidence from the Lherz peridotites, French Pyrenees, Terra Nov., 20, 11-21, https://doi.org/10.1111/j.1365-3121.2007.00781.x, 2008.

Lagabrielle, Y., Labaume, P., and De Saint Blanquat, M.: Mantle exhumation, crustal denudation, and gravity tectonics during Cretaceous rifting in the Pyrenean realm (SW Europe): Insights from the geological setting of the lherzolite bodies, Tectonics, 29, 126, https://doi.org/10.1029/2009TC002588, 2010.

Le Pichon, X. and Sibuet, J.: Western extension and boundary between European and Iberian Plates during the Pyrenean Orogeny, Earth Planet. Sc. Lett., 12, 83-88, https://doi.org/10.1016/0012821X(71)90058-6, 1971.

Levi, S. and Riddihough, R.: Why are marine magnetic anomalies suppressed over sedimented spreading centers?, Geology, 14, 651-654, https://doi.org/10.1130/00917613(1986)14<651:WAMMAS>2.0.CO;2, 1986

Lister, G. S., Etheridge, M. A., and Symonds, P. A.: Detachment faulting and the evolution of passive continental margins, Geology, 14, 246-250, https://doi.org/10.1130/00917613(1986)14<246:DFATEO>2.0.CO;2, 1986.

Macchiavelli, C., Vergés, J., Schettino, A., Fernàndez, M., Turco, E., Casciello, E., Torne, M., Pierantoni, P. P., and Tunini, L.: A New Southern North Atlantic Isochron Map: Insights Into the Drift of the Iberian Plate Since the Late Cretaceous, J. Geophys. Res.-Sol. Ea., 122, 9603-9626, https://doi.org/10.1002/2017JB014769, 2017.

Magee, C., Hunt-Stewart, E., and Jackson, C. A.-L.: Volcano growth mechanisms and the roll of sub-volcanic intrusions: Insights from 2D seismic reflection data, Earth Planet. Sc. Lett., 373, 4153, https://doi.org/10.1016/j.eps1.2013.04.041, 2013. 
Malod, J. A. and Mauffret, A.: Iberian plate motions during the Mesozoic, Tectonophysics, 184, 261-278, https://doi.org/10.1016/0040-1951(90)90443-C, 1990.

Manatschal, G. and Bernoulli, D.: Rifting and early evolution of ancient ocean basins: The record of the Mesozoic Tethys and of the Galicia-Newfoundland margins, Mar. Geophys. Res., 20, 371381, https://doi.org/10.1023/A:1004459106686, 1998.

Manatschal, G. and Bernoulli, D.: Architecture and tectonic evolution of nonvolcanic margins: Present-day Galicia and ancient Adria, Tectonics, 18, 1099-1119, https://doi.org/10.1029/1999TC900041, 1999.

Manatschal, G., Froitzheim, N., Rubenach, M., and Turrin, B. D.: The role of detachment faulting in the formation of an ocean-continent transition: insights from the Iberia Abyssal Plain, Geol. Soc. Spec. Publ., 187, 405-428, https://doi.org/10.1144/gsl.sp.2001.187.01.20, 2001.

Manspeizer, W.: Triassic - Jurassic rifting and opening of the Atlantic: An overview, Developments in Geotectonics, 22, 41-79, https://doi.org/10.1016/B978-0-444-42903-2.50008-7, 1988.

Masini, E., Manatschal, G., Tugend, J., Mohn, G., and Flament, J.M.: The tectono-sedimentary evolution of a hyper-extended rift basin: The example of the Arzacq-Mauléon rift system (Western Pyrenees, SW France), Int. J. Earth Sci., 103, 1569-1596, https://doi.org/10.1007/s00531-014-1023-8, 2014.

Masson, D. G. and Miles, P. R.: Mesozoic seafloor spreading between Iberia, Europe and North America, Mar. Geol., 56, 279287, https://doi.org/10.1016/0025-3227(84)90019-7, 1984.

Matthews, D. H. and Williams, C. A.: Linear Magnetic Anomalies in the Bay of Biscay?: A Qualitative Interpretation, Earth Planet. Sc. Lett., 4, 315-320, https://doi.org/10.1016/0012821X(68)90094-0, 1968.

Mauffret, A. and Montadert, L.: Rift tectonics on the passive continental margin off Galicia (Spain), Mar. Petrol. Geol., 4, 49-70, https://doi.org/10.1016/0264-8172(87)90021-3, 1987.

Mauffret, A., Mougenot, D., Miles, P. R., and Malod, J. A.: Cenozoic deformation and Mesozoic abandoned spreading centre in the Tagus Abyssal Plain (west of Portugal): results of a multichannel seismic survey, Can. J. Earth Sci., 26, 1101-1123, https://doi.org/10.1139/e89-095, 1989.

McClay, K., Munoz, J. A., and García-Senz, J.: Extensional salt tectonics in a contractional orogen: A newly identified tectonic event in the Spanish Pyrenees, Geology, 32, 737-740, https://doi.org/10.1130/G20565.1, 2004.

Minshull, T. A., Dean, S. M., Whitmarsh, R. B., Russell, S. M., Louden, K. E., and Chian, D.: Deep structured the vicinity of the ocean-continent transition zone under the southern Iberia Abyssal Plain, Geology, 26, 743-746, https://doi.org/10.1130/00917613(1998)026<0743:DSITVO>2.3.CO;2, 1998.

Mohn, G., Manatschal, G., Beltrando, M., Masini, E., and Kusznir, N.: Necking of continental crust in magma-poor rifted margins: Evidence from the fossil Alpine Tethys margins, Tectonics, 31, 1-28, https://doi.org/10.1029/2011TC002961, 2012.

Müller, R. D., Roest, W. R., Royer, J.-Y., Gahagan, L. M., and Sclater, J. G.: Digital isochrons of the world's ocean floor, J. Geophys. Res.-Sol. Ea., 102, 3211-3214, https://doi.org/10.1029/96jb01781, 1997.

Müller, R. D., Sdrolias, M., Gaina, C., Roest, and W. R.: Age, spreading rates, and spreading asymmetry of the world's ocean crust, Geochem. Geophy. Geosy., 9, 1-19, https://doi.org/10.1029/2007GC001743, 2008.

Müller, R. D., Zahirovic, S., Williams, S. E., Cannon, J., Seton, M., Bower, D. J., Tetley, M. G., Heine, C., Le Breton, E., Liu, S., Russell, S. H. J., Yang, T., Leonard, J., and Gurnis, M.: A Global Plate Model Including Lithospheric Deformation Along Major Rifts and Orogens Since the Triassic, Tectonics, 38, 1884-1907, https://doi.org/10.1029/2018TC005462, 2019.

Muñoz, J. A.: The Pyrenees, in: The geology of Spain, edited by: Gibbons, W. and Moreno, T., Geol. Soc. London, 370-385, 2002.

Neves, M. C., Terrinha, P., Afilhado, A., Moulin, M., Matias, L., and Rosas, F.: Response of a multi-domain continental margin to compression: Study from seismic reflection-refraction and numerical modelling in the Tagus Abyssal Plain, Tectonophysics, 468, 113-130, https://doi.org/10.1016/j.tecto.2008.05.008, 2009.

Nirrengarten, M., Manatschal, G., Tugend, J., Kusznir, N. J., and Sauter, D.: Nature and origin of the J-magnetic anomaly offshore Iberia-Newfoundland: implications for plate reconstructions, Terra Nov., 29, 20-28, https://doi.org/10.1111/ter.12240, 2017.

Nirrengarten, M., Manatschal, G., Tugend, J., Kusznir, N., and Sauter, D.: Kinematic Evolution of the Southern North Atlantic: Implications for the Formation of Hyperextended Rift Systems, Tectonics, 37, 89-118, https://doi.org/10.1002/2017TC004495, 2018.

Olivet, J. L.: Kinematics of the Iberian Plate, Bulletin des Centres de Recherches Exploration - Production Elf Aquitaine, 20, 131195, 1996.

Olivet, J. L., Bonnin, J., Beuzart, P., and Auzende, J.-M.: Cinématique de l'Atlantique Nord et Central, Publ. du C.N.E.X.O. Série Rapports Sci. Tech., 54, 1-108, 1984.

Peace, A. L., Welford, J. K., Ball, P. J., and Nirrengarten, M.: Deformable plate tectonic models of the southern North Atlantic, J. Geodyn., 128, 11-37, https://doi.org/10.1016/j.jog.2019.05.005, 2019.

Peirce, C. and Barton, P.: Crustal structure of the MadeiraTore Rise, eastern North Atlantic - results of a DOBS wide-angle and normal incidence seismic experiment in the Josephine Seamount region, Geophys. J. Int., 106, 357-378, https://doi.org/10.1111/j.1365-246X.1991.tb03898.x, 1991.

Pereira, R. and Alves, T. M.: Margin segmentation prior to continental break-up: A seismic-stratigraphic record of multiphased rifting in the North Atlantic (Southwest Iberia), Tectonophysics, 505, 17-34, https://doi.org/10.1016/j.tecto.2011.03.011, 2011.

Pérez-Gussinyé, M. and Reston, T. J.: Rheological evolution during extension at nonvolcanic rifted margins: Onset of serpentinization and development of detachments leading to continental breakup, J. Geophys. Res.-Sol. Ea., 106, 3961-3975, https://doi.org/10.1029/2000JB900325, 2001.

Péron-Pinvidic, G. and Manatschal, G.: The final rifting evolution at deep magma-poor passive margins from Iberia-Newfoundland: A new point of view, Int. J. Earth Sci., 98, 1581-1597, https://doi.org/10.1007/s00531-008-0337-9, 2009.

Péron-Pinvidic, G., Manatschal, G., Minshull, T. A., and Sawyer, D. S.: Tectonosedimentary evolution of the deep IberiaNewfoundland margins: Evidence for a complex breakup history, Tectonics, 26, 1-19, https://doi.org/10.1029/2006TC001970, 2007. 
Pinheiro, L. M., Whitmarsh, R. B., and Miles, P. R.: The ocean-continental boundary off the western continental continental margin of Iberia - II. Crustal structure in the Tagus Abyssal Plain, Geophys. J. Int., 109, 106-124, https://doi.org/10.1111/j.1365-246X.1992.tb00082.x, 1992.

Pinheiro, L. M., Wilson, R. C., Pena dos Reis, R., Whitmarsh, R. B., and Ribeiro, A.: The Western Iberia Margin: a Geophysical and Geological Overview, Proc. Ocean Drill. Program, Sci. Results, 149, 3-23, https://doi.org/10.2973/odp.proc.sr.149.246.1996, 1996.

Pitman, W. C. and Talwani, M.: Sea-Floor Spreading in the North Atlantic, Geol. Soc. Am. Bull., 83, 619-646, https://doi.org/10.1130/00167606(1972)83[619:SSITNA]2.0.CO;2, 1972.

Planke, S., Rasmussen, T., Rey, S. S., and Myklebust, R.: Seismic characteristics and distribution of volcanic intrusions and hydrothermal vent complexes in the Vøring and Møre basins, Pet. Geol. North-west Eur., 6, 833-844, https://doi.org/10.1144/0060833, 2005.

Rabinowitz, P., Cande, S., Hayes, D., Gradstein, F., Grant, A., and Jansa, L.: Grand Banks and J-Anomaly Ridge, Science, 323, 721-723, https://doi.org/10.1126/science.202.4363.71, 1978.

Reid, I. D.: Crustal structure of a nonvolcanic rifted margin east of Newfoundland, J. Geophys. Res., 99, 15161-15180, https://doi.org/10.1029/94JB00935, 1994.

Reston, T. J.: The formation of non-volcanic rifted margins by the progressive extension of the lithosphere: the example of the West Iberian margin, Geol. Soc. Spec. Publ., 282, 77-110, https://doi.org/10.1144/SP282.5, 2007.

Reston, T. J. and Morgan, J. P.: Continental geotherm and the evolution of rifted margins, Geology, 32, 133-136, https://doi.org/10.1130/G19999.1, 2004.

Roest, W. R. and Srivastava, S. P.: Kinematics of the plate boundaries between Eurasia, Iberia, and Africa in the North Atlantic from the Late Cretaceous to the present, Geology, 19, 613-616, https://doi.org/10.1130/00917613(1991)019<0613:KOTPBB>2.3.CO;2, 1991.

Rosenbaum, G., Lister, G. S., and Duboz, C.: Reconstruction of the tectonic evolution of the western Mediterranean since the Oligocene, J. Virtual Explor., 8, 107-130, https://doi.org/10.3809/jvirtex.2002.00053, 2002.

Rowley, D. and Lottes, A.: Plate-kinematic reconstructions of the North Atlantic and Arctic: Late Jurassic to Present, Tectonophysics, 155, 73-120, https://doi.org/10.1016/00401951(88)90261-2, 1988.

Russell, S. M. and Whitmarsh, R. B.: Magmatism at the west Iberia non-volcanic rifted continental margin: Evidence from analyses of magnetic anomalies, Geophys. J. Int., 154, 706-730, https://doi.org/10.1046/j.1365-246X.2003.01999.x, 2003.

Sandoval, L., Welford, J. K., MacMahon, H., and Peace, A. L.: Determining continuous basins across conjugate margins: The East Orphan, Porcupine, and Galicia Interior basins of the southern North Atlantic Ocean, Mar. Petrol. Geol., 110, 138-161, https://doi.org/10.1016/j.marpetgeo.2019.06.047, 2019.

Schoeffler, J.: Une hypothese sur la tectogenese de la chaine pyreneenne et de ses abords, Bull. Soc. Geol. Fr., 7, 917-920, 1965.

Sclater, J. G., Hellinger, S., and Tapscott, C.: The Paleobathymetry of the Atlantic Ocean from the Jurassic to the Present, J. Geol., 85, 509-552, https://doi.org/10.1086/628336, 1977.
Searle, R.: Tectonic pattern of the Azores spreading centre and triple junction, Earth Planet. Sc. Lett., 51, 415-434, https://doi.org/10.1016/0012-821X(80)90221-6, 1980.

Seton, M., Müller, R. D., Zahirovic, S., Gaina, C., Torsvik, T., Shephard, G., Talsma, A., Gurnis, M., Turner, M., Maus, S., and Chandler, M.: Global continental and ocean basin reconstructions since $200 \mathrm{Ma}$, Earth-Sci. Rev., 113, 212-270, https://doi.org/10.1016/j.earscirev.2012.03.002, 2012.

Shillington, D. J., Holbrook, W. S., Van Avendonk, H. J. A., Tucholke, B. E., Hopper, J. R., Louden, K. E., Larsen, H. C., and Nunes, G. T.: Evidence for asymmetric nonvolcanic rifting and slow incipient oceanic accretion from seismic reflection data of the Newfoudland margin, J. Geophys. Res.-Sol. Ea., 111, B09402, https://doi.org/10.1029/2005JB003981, 2006.

Sibuet, J. C. and Collette, B.: Triple junctions of Bay of Biscay and North Atlantic: new constraints on the kinematic evolution, Geology, 19, 522-525, https://doi.org/10.1130/00917613(1991)019<0522:TJOBOB>2.3.CO;2, 1991.

Sibuet, J. C. and Srivastava, S. P.: Rifting consequences of three plate separation, Geophys. Res. Lett., 21, 521-524, https://doi.org/10.1029/93GL03304, 1994.

Sibuet, J. C., Srivastava, S. P., and Spakman, W.: Pyrenean orogeny and plate kinematics, J. Geophys. Res.-Sol. Ea., 109, 1-18, https://doi.org/10.1029/2003JB002514, 2004.

Sibuet, J. C., Srivastava, S. P., Enachescu, M., and Karner, G. D.: Early Cretaceous motion of Flemish Cap with respect to North America: implications on the formation of Orphan Basin and SE Flemish Cap-Galicia Bank conjugate margins, Geol. Soc. Spec. Publ., 282, 63-76, https://doi.org/10.1144/SP282.4, 2007.

Sibuet, J. C., Rouzo, S., and Srivastava, S. P.: Plate tectonic reconstructions and paleogeographic maps of he central and North Atlantic Oceans, Can. J. Earth Sci., 49, 1567-1594, https://doi.org/10.1139/e2012-075, 2012.

Skogseid, J.: The Orphan Basin - a key to understanding the kinematic linkage between North and NE Atlantic Mesozoic rifting, II Cent. North Atl. Conjug. Margins Conf. II, 13-23, 2010.

Smith, W. H. F. and Sandwell, D. T: Global seafloor topography from satellite altimetry and ship depth soundings, Science, 277, 1957-1962, https://doi.org/10.1126/science.277.5334.1956, 1997.

Soares, D. M., Alves, T. M., and Terrinha, P.: The breakup sequence and associated lithospheric breakup surface: Their significance in the context of rifted continental margins (West Iberia and Newfoundland margins, North Atlantic), Earth Planet. Sc. Lett., 355356, 311-326, https://doi.org/10.1016/j.epsl.2012.08.036, 2012.

Srivastava, S. P. and Tapscott, C. R.: Plate kinematics of the North Atlantic, in: The Western North Atlantic Region, edited by: Vogt, P. R. and Tucholke, B. E., Geol. Soc. Am., 379-404, https://doi.org/10.1130/dnag-gna-m.379, 1986.

Srivastava, S. P. and Verhoef, J.: Evolution of Mesozoic sedimentary basins around the North Central Atlantic?: a preliminary plate kinematic solution, Geol. Soc. Spec. Publ., 62, 397-420, https://doi.org/10.1144/GSL.SP.1992.062.01.30, 1992.

Srivastava, S. P., Schouten, H., Roest, W., Klitgord, K., Kovacs, L. C., Verhoef, J., and Macnab, R.: Iberian plate kinematics: a jumping plate boundary between Eurasia and Africa, Nature, 334, 756-759, https://doi.org/10.1038/344756a0, 1990.

Srivastava, S. P., Sibuet, J. C., Cande, S., Roest, W. R., and Reid, I. D.: Magnetic evidence for slow seafloor spreading during 
the formation of the Newfoundland and Iberian margins, Earth Planet. Sc. Lett., 182, 61-76, https://doi.org/10.1016/S0012821X(00)00231-4, 2000.

Stampfli, G., Borel, G., Marchant, R., and Mosar, J.: Western Alps geological constraints on western Tethyan reconstructions The geodynamic framework of the western Alps, J. Virtual Explor., 8, 75-104, https://doi.org/10.3809/jvirtex.2002.00057, 2002.

Stanton, N., Manatschal, G., Autin, J., Sauter, D., Maia, M., and Viana, A.: Geophysical fingerprints of hyper-extended, exhumed and embryonic oceanic domains: the example from the IberiaNewfoundland rifted margins, Mar. Geophys. Res., 37, 185-205, https://doi.org/10.1007/s11001-016-9277-0, 2016.

Sullivan, K. D.: The Newfoundland Basin: ocean-continent boundary and Mesozoic seafloor spreading history, Earth Planet. Sc. Lett., 62, 321-339, https://doi.org/10.1016/0012821X(83)90003-1, 1983.

Tavani, S., Bertok, C., Granado, P., Piana, F., Salas, R., Vigna, B., and Muñoz, J. A.: The Iberia-Eurasia plate boundary east of the Pyrenees, Earth-Sci. Rev., 187, 314-337, https://doi.org/10.1016/j.earscirev.2018.10.008, 2018.

Teixell, A., Labaume, P., Ayarza, P., Espurt, N., de Saint Blanquat, M., and Lagabrielle, Y.: Crustal structure and evolution of the Pyrenean-Cantabrian belt: A review and new interpretations from recent concepts and data, Tectonophysics, 724-725, 146-170, https://doi.org/10.1016/j.tecto.2018.01.009, 2018.

Tucholke, B. and Ludwig, W. J.: Structure and origin of the $\mathrm{J}$ Anomaly Ridge, western North Atlantic Ocean, J. Geophys. Res.-Sol. Ea., 87, 9389-9407, https://doi.org/10.1029/JB087iB11p09389, 1982.

Tucholke, B. E. and Sibuet, J.-C.: Leg 210 Synthesis: Tectonic, Magmatic, and Sedimentary Evolution of the NewfoundlandIberia Rift, Proc. Ocean Drill. Program, 210 Sci. Results, 210, 1-56, https://doi.org/10.2973/odp.proc.sr.210.101.2007, 2007.

Tucholke, B. E., Austin, J. A, and Uchupi, E.: Crustal structure and rift-drift evolation of the Newfoundland Basin, in: Extensional Tectonics and Stratigraphy of the North Atlantic Margins, edited by: Tankard, A. J. and Balkwell, H. R., AAPG Mem, 46, 247263, 1989.

Tucholke, B. E., Sawyer, D. S., and Sibuet, J.-C.: Breakup of the Newfoundland Iberia rift, Geol. Soc. Spec. Publ., 282, 9-46, https://doi.org/10.1144/SP282.2, 2007.

Tugend, J., Manatschal, G., Kusznir, N. J., Masini, E., Mohn, G., and Thinon, I.: Formation and deformation of hyperextended rift systems: Insights from rift domain mapping in the Bay of Biscay-Pyrenees, Tectonics, 33, 1239-1276, https://doi.org/10.1002/2014TC003529, 2014.

Tugend, J., Manatschal, G., and Kusznir, N. J.: Spatial and temporal evolution of hyperextended rift systems: Implication for the nature, kinematics, and timing of the Iberian- European plate boundary, Geology, 43, 15-18, https://doi.org/10.1130/G36072.1, 2015.

Tugend, J., Gillard, M., Manatschal, G., Nirrengarten, M., Harkin, C., Epin, M.-E., Sauter, D., Autin, J., Kusznir, N., and McDermott, K.: Reappraisal of the magma-rich versus magmapoor rifted margin archetypes, Geol. Soc. London, 476, https://doi.org/10.1144/SP476.9, 2018.

Van der Voo, R.: Paleomagnetic evidence for the rotation of the Iberian Peninsula, Tectonophysics, 7, 5-56, https://doi.org/10.1016/0040-1951(69)90063-8, 1969.
Van der Voo, R. and Boessenkool, A.: Permian paleomagnetic result from the Western Pyrenees delineating the plate boundary between the Iberian Peninsula and Stable Europe, J. Geophys. Res., 78, 5118-5127, https://doi.org/10.1029/jb078i023p05118, 1973.

Vauchez, A., Clerc, C., Bestani, L., Lagabrielle, Y., Chauvet, A., Lahfid, A., and Mainprice, D.: Preorogenic exhumation of the North Pyrenean Agly massif (Eastern Pyrenees-France), Tectonics, 32, 95-106, https://doi.org/10.1002/tect.20015, 2013.

Vissers, R. L. M. and Meijer, P. T.: Mesozoic rotation of Iberia: Subduction in the Pyrenees? Earth-Sci. Rev., 110, 93-110, https://doi.org/10.1016/j.earscirev.2011.11.001, 2011.

Vissers, R. L. M. and Meijer, P. T.: Iberian plate kinematics and Alpine collision in the Pyrenees, Earth-Sci. Rev., 114, 61-83, https://doi.org/10.1016/j.earscirev.2012.05.001, 2012.

Wessel, P. and Smith, W. H. F.: Free software helps map and display data, Eos T. Am. Geophys. Un., 72, 441-446, https://doi.org/10.1029/90EO00319, 1991.

Whitmarsh, R. and Miles, P.: Models of the development of the west Iberia rifted continental margin at $40^{\circ} 30^{\prime} \mathrm{N}$ deduced from surface and deep-tow magnetic anomalies, J. Geophys. Res., 100, 3789-3806, https://doi.org/10.1029/94JB02877, 1995.

Whitmarsh, R. B. and Sawyer, D. S.: The ocean/continent transition beneath the Iberia Abyssal Plain and continental-rifting to seafloor-spreading processes, Proc. Ocean Drill. Progr., 149, 713-736, https://doi.org/10.2973/odp.proc.sr.149.249.1996, 1996.

Whitmarsh, R. B. and Wallace, P. J.: The rift-to-drift development of the west Iberia nonvolcanic continental margin: a summary and review of the contribution of Ocean Drilling Program Leg 173, Proc. Ocean Drill. Program, Sci. Result, 173, 1-36, https://doi.org/10.2973/odp.proc.sr.173.017.2001, 2001.

Whitmarsh, R. B., Beslier, M.-O., Wallace, P. J., Natsue, A., Basile, C., Beard, J. S., Froitxhein, N., Véronique, H., Hopkinson, R., Laurence, J., Kudless, K. E., Louvel, V., Manatschal, G., Newton, A. C., Rubenachn M. J., Skelton, A. D. L., Smith, S. E., Takayama, H., Tompkins, M. J., Turrin, B. D., Urquhart, E., Wallrabe-Adams, H.-J., Wilkens, R. H., Wilson, R. C. L., Wise, S. W., and Zhao, X.: Proceedings of the Ocean Drilling Program, Initial reports; return to Iberia; covering Leg 173 of the cruises of the drilling vessel JOIDES Resolution, Lisbon, Portugal, to Halifax, Nova Scotia, 1065-1070, 15 April-15 June 1997, College Station, TX: Texas A\&M University, Ocean Drilling Program, College Station, TX, USA, https://doi.org/10.2973/odp.proc.ir.173.1998, 1988.

Whitmarsh, R. B., White, R. S., Horsefield, S. J., Sibuet, J.C., Recq, M., and Louvel, V.: The ocean-continent boundary off the western continental margin of Iberia: Crustal structure west of Galicia Bank, J. Geophys. Res., 101, 28291, https://doi.org/10.1029/96JB02579, 1996.

Wilson, R. C. L., Hiscott, R. N., Willis, M. G., and Gradstein, F.: The Lusitanian Basin of West Central Portugal: Mesozoic and Tertiary tectonic, stratigraphic and subsidence history, in: Extensional Tectonics of the North Atlantic Margins, edited by: Tankard, A. J. and Balkwell, H. R., AAPG Mem, 46, 341-361, 1989.

Wilson, R. C. L., Sawyer, D. S., Whitmarsh, R. B., Zerong, J., and Carbonell, J.: Seismic stratigraphy and tectonic history of the Iberia Abyssal Plain, Proc. 
Ocean Drill. Program, 149 Sci. Results, 149, 617-633, https://doi.org/10.2973/odp.proc.sr.149.245.1996, 1996.

Wilson, R. C. L., Manatschal, G., and Wise, S.: Rifting along non-volcanic passive margins: stratigraphic and seismic evidence from the Mesozoic successions of the Alps and western Iberia, Geol. Soc. Spec. Publ., 187, 429-452, https://doi.org/10.1144/gsl.sp.2001.187.01.21, 2001.
Zitellini, N., Gràcia, E., Matias, L., Terrinha, P., Abreu, M. A., De Alteriis, G., Henriet, J. P., Dañobeitia, J. J., Masson, D. G., Mulder, T., Ramella, R., Somoza, L., and Diez, S.: The quest for the Africa-Eurasia plate boundary west of the Strait of Gibraltar, Earth Planet. Sc. Lett., 280, 13-50, https://doi.org/10.1016/j.eps1.2008.12.005, 2009. 